\title{
Translational Control of Myelin Basic Protein Expression by ERK2 MAP Kinase Regulates Timely Remyelination in the Adult Brain
}

\author{
Kelly Michel, Tianna Zhao, Molly Karl, Katherine Lewis, and Sharyl L. Fyffe-Maricich \\ Department of Pediatrics, Division of Neurology, University of Pittsburgh, Pittsburgh, Pennsylvania 15224
}

\begin{abstract}
Successful myelin repair in the adult CNS requires the robust and timely production of myelin proteins to generate new myelin sheaths. The underlying regulatory mechanisms and complex molecular basis of myelin regeneration, however, remain poorly understood. Here, we investigate the role of ERK MAP kinase signaling in this process. Conditional deletion of Erk2 from cells of the oligodendrocyte lineage resulted in delayed remyelination following demyelinating injury to the adult mouse corpus callosum. The delayed repair occurred as a result of a specific deficit in the translation of the major myelin protein, MBP. In the absence of ERK2, activation of the ribosomal protein S6 kinase (p70S6K) and its downstream target, ribosomal protein S6 (S6RP), was impaired at a critical time when premyelinating oligodendrocytes were transitioning to mature cells capable of generating new myelin sheaths. Thus, we have described an important link between the ERK MAP kinase signaling cascade and the translational machinery specifically in remyelinating oligodendrocytes in vivo. These results suggest an important role for ERK2 in the translational control of MBP, a myelin protein that appears critical for ensuring the timely generation of new myelin sheaths following demyelinating injury in the adult CNS.
\end{abstract}

Key words: demyelination; ERK2 MAP kinase; myelin; oligodendrocyte; remyelination

\section{Introduction}

Throughout early postnatal development, oligodendrocyte progenitor cells (OPCs) proliferate, migrate, differentiate, and myelinate CNS axons on a predictable schedule (Miller, 2002). The regenerative process of remyelination following demyelinating injury in the adult CNS is thought to proceed through similar mechanisms, although less is understood about the molecular regulation of oligodendrocyte (OL) development in this context (Fancy et al., 2011; Gallo and Deneen, 2014). A more complete appreciation of the relationship between developmental myelination and remyelination will provide a better understanding of human CNS demyelinating disorders such as multiple sclerosis (MS). Remyelination ultimately fails in MS patients, resulting in functional disability as the disease progresses (Prineas and Connell, 1979; Lucchinetti et al., 1996; Patrikios et al., 2006). The reasons for remyelination failure in MS are not completely understood, although a failure in OPC differentiation and/or maturation

\footnotetext{
Received Oct. 22, 2014; revised April 17, 2015; accepted April 19, 2015.

Author contributions: S.L.F.-M. designed research; K.M., T.Z., M.K., K.L., and S.L.F.-M. performed research; K.M. and S.L.F.-M. analyzed data; S.L.F.-M. wrote the paper.

This work was supported in part by an NMSS Career-Transition Fellowship to S.F.-M. and grants to S.F.-M. from the National Institutes of Health (NS091084) and Children's Hospital of Pittsburgh of the University of Pittsburgh Medical Center Health System. We thank Dr. K. Nave (Max Plank Institute, Germany) for the CNP-Cre mice and Dr. Gary Landreth (Case Western Reserve University) for the Erk2 flox mice. We also thank Alexandra Schott for technical assistance and Robert Miller, Stephen Maricich, and Jenna Gaesser for helpful discussions and comments on this manuscript.

The authors declare no competing financial interests.

Correspondence should be addressed to Sharyl L. Fyffe-Maricich, University of Pittsburgh, One Children's Hospital Drive, 4401 Penn Avenue, RRB Rm 3512, Pittsburgh, PA 15224. E-mail: sharyl.fyffemaricich@chp.edu.

DOI:10.1523/JNEUROSCI.4380-14.2015

Copyright $\odot 2015$ the authors $\quad 0270-6474 / 15 / 357850-16 \$ 15.00 / 0$
}

has been suggested based on postmortem findings (Wolswiik, 1998; Chang et al., 2000, 2002; Kuhlmann et al., 2008). Efficient and timely remyelination can lead to complete functional recovery (Smith et al., 1979, 1981; Jeffery and Blakemore, 1997; Duncan et al., 2009); therefore, identifying the molecular mechanisms important for successful remyelination is essential for the development of new therapies targeted to restore lost myelin.

Previous studies investigating roles of molecules and signaling pathways important for developmental myelination in the context of remyelination have yielded mixed results. For example, the transcription factor Olig1 plays important roles during development (Lu et al., 2002; Dai et al., 2015) and is critical during myelin repair (Arnett et al., 2004). Wnt/ $\beta$-catenin and Sonic Hedgehog signaling are also important both during development and following demyelination (Orentas et al., 1999; Spassky et al., 2001; Fancy et al., 2009; Ferent et al., 2013). More recent evidence suggests that sustained activation of ERK1 and ERK2 causes significant increases in myelin thickness both during development and following demyelinating injury in the adult mouse spinal cord (Fyffe-Maricich et al., 2013). In contrast, the phosphatase and tensin homolog (PTEN) that regulates PI3K signaling is important for proper myelin thickness and axonal integrity during development but appears dispensable for myelin repair (Harrington et al., 2010).

ERK MAP kinases are critical intracellular molecules that transduce extracellular signals at multiple stages of OL development, and ERK2 plays a specific role in the timing of mouse forebrain myelination during the second postnatal week (FyffeMaricich et al., 2011). In the current study, we conditionally de- 
leted Erk2 from OL-lineage cells to determine whether Erk2 was also required for timely myelin production following focal demyelination in the adult CNS. We found that ERK2 controls the timing of remyelination not through effects on OPC proliferation, migration, or differentiation, but by directly regulating the efficient translation of the major myelin protein, myelin basic protein (MBP). To explore a potential mechanism for this translational defect, we examined the activation of important components of the translational machinery. We found that Erk2 conditional knock-out (CKO) OLs were unable to sufficiently activate the ribosomal protein S6 kinase (p70S6K), resulting in decreased phosphorylation and activation of its downstream target, S6 ribosomal protein (S6RP). These results provide important insight into the molecular mechanisms that act downstream of the ERK MAP kinase signaling pathway and point to a critical role for translational control during remyelination.

\section{Materials and Methods}

Experimental animals. Heterozygous CNP-Cre mice (Lappe-Siefke et al., 2003) on a mixed 129 C57BL/6 background were interbred with homozygous Erk2flox mice (Samuels et al., 2008) to generate CNP-Cre; Erk2flox/+ breeders. CNP-Cre; Erk2flox/+ mice were then interbred with either Erk2flox/flox or Erk2flox/+ mice to produce CNP-Cre; Erk2flox/flox, referred to as "mutants" or "Erk2 CKO" mice, and "controls," which consisted of [WT; Erk2flox/flox], [WT; Erk2 flox/+], and/or [CNP-Cre; $+/+$ ] littermates. Age and sex-matched male and female mice were used for all experiments. All mice were kept in microisolation in a pathogen-free environment at the University of Pittsburgh, and all procedures were conducted according to approved Institutional Animal Care and Use Committee guidelines.

Demyelination by lysolecithin injection. All injections were performed on sex-matched pairs of control and mutant adult mice aged 12-16 weeks. Mice were deeply anesthetized and positioned in the stereotaxic frame (Harvard Apparatus). Then $1.5 \mu \mathrm{l}$ of $1 \% \mathrm{~L}-\alpha$-lysophosphatidylcholine (LPC; Sigma) in a $0.9 \%$ sodium chloride solution was microinjected at a rate of $8.33 \mathrm{nl} / \mathrm{s}$ using a sterile beveled needle and Hamilton syringe. Mice were injected unilaterally into the right corpus callosum using the following stereotaxic coordinates (relative to bregma): $1.1 \mathrm{~mm}$ rostral, $1.0 \mathrm{~mm}$ lateral, $1.8 \mathrm{~mm}$ deep (relative to the surface of the brain). To prevent liquid reflux at the completion of the injection, the needle was left in place for $3 \mathrm{~min}$ before removal. The day of injection was considered $0 \mathrm{~d}$ post lesion $(\mathrm{dpl})$.

Quantification of lesion size. Lesioned area was determined by staining serial coronal sections through the corpus callosum with luxol fast blue (LFB) to define the borders of the demyelinated area in all three dimensions. 3D-Doctor software (Able Software) was then used to reconstruct each $3 \mathrm{D}$ lesion and to quantify the volume. Between three and seven mice were analyzed per genotype at each time point.

Immunolabeling of frozen sections. Mice were perfused in 4\% PFA/PBS, postfixed overnight, and cryoprotected in $20 \%$ sucrose/PBS. Coronal cryosections $(20 \mu \mathrm{m})$ of brain were rinsed in PBS; exposed to antigen retrieval in citrate buffer, $\mathrm{pH}$ 6.0, for $10 \mathrm{~min}$; washed with PBS; and then blocked and permeabilized with $0.3 \%$ Triton X-100 and $4 \%$ goat serum in PBS for $30 \mathrm{~min}$. Sections were incubated with primary antibodies at $4^{\circ} \mathrm{C}$ overnight, then incubated with secondary antibodies at room temperature for $1 \mathrm{~h}$. Sections were counterstained with DAPI for $3 \mathrm{~min}$. Primary antibodies used were MBP (1:1000; SMI-99; Covance), CC1 (1:100; anti-APC; Calbiochem), Ki67 (1:250; BD Biosciences), OLIG2 (1:250; Millipore), NeuN (1:250; Millipore), GFAP (1:1000; Dako Cytomation), ERK2 (1:250; Santa Cruz Biotechnology), pERK1/2 (rabbit-1: 250; Cell Signaling Technology and mouse-1:250; Santa Cruz Biotechnology), IBA1 (1:500; Wako), PLP (1:500; Abcam), MOG (1:250; Santa Cruz Biotechnology), pS6RP Ser240/244 (1:2000; Cell Signaling Technology), anti-pS6RP Ser235/236 (1:1000; Cell Signaling Technology), pmTOR Ser2448 (1:100; Cell Signaling Technology), and pp70S6K Thr421/Ser424 (1:500; Santa Cruz Biotechnology). Alexa Fluorconjugated IgG (1:500; Invitrogen) was used for secondary antibodies.
Myelin loss was identified using standard LFB histochemical staining ( $0.1 \%$ solution; Electron Microscopy Sciences) and immunostaining for MBP.

Cell counts. For cell number counts in the lesioned tissue, images were acquired from the same area of the lesion ensuring that sections were matched on both a rostrocaudal level as well as mediolateral. LFB and MBP stainings of adjacent sections were used to identify the lesion borders in all dimensions. Cells were counted blindly from at least two sections and from a minimum of three mice per genotype using NISElements software (Nikon Instruments). The same region of the corpus callosum from the contralateral side was analyzed for counts from uninjured tissue. An identical region of interest was created on each image to ensure that an equivalent area of demyelination (or uninjured callosum) was analyzed for each animal. Results are presented as the total number of immunopositive cells per lesion area measured or as the percentage of $\mathrm{CC} 1+$ cells that express the protein of interest within the region of interest. NIS-Elements software was also used to determine the percentage of lesioned area with immunopositive cells for Figures 4 and 7. Sections were matched as described above and a binary analysis was performed to calculate the percentage of the area of interest with immunopositive cells.

Fluorescence intensity. NIS-Elements software (Nikon Instruments) was used to determine the sum pERK fluorescence intensity of single $\mathrm{CC} 1+$ cells selected from within the lesioned area from Erk2 CKO and control littermates.

Immunoblotting. Immunoblotting was performed essentially as previously described (Fyffe-Maricich et al., 2011). The lesioned area of corpus callosum was carefully microdissected using a dissecting microscope, homogenized by sonication in RIPA lysis buffer (Sigma-Aldrich) containing protease and phosphatase inhibitors (Halt protease and phosphatase inhibitor cocktail; Thermo Fisher Scientific) and centrifuged at 10 $000 \times g$ for $10 \mathrm{~min}$ at $4^{\circ} \mathrm{C}$. An equal amount of total protein lysate was loaded from four mice per genotype onto $4-20 \%$ gradient SDS-PAGE gels, transferred to PVDF membranes, and probed overnight at $4^{\circ} \mathrm{C}$ using the following primary antibodies: pERK1/2 (1:1000; Cell Signaling Technology), GAPDH (1:10,000; Santa Cruz Biotechnology), ERK2 (1:1000; Santa Cruz Biotechnology), pS6RP Ser235/236 (1:1000; Cell Signaling Technology), pS6RP Ser240/244 (1:1000; Cell Signaling Technology), S6RP (1:1000; Cell Signaling Technology), mTOR (1:1500; Cell Signaling Technology), pmTOR Ser2448 (1:1500; Cell Signaling Technology), ERK1 (1:1000; Cell Signaling Technology), p70S6K (1:500; Cell Signaling Technology), pp70S6K Thr389 (1:1000; Cell Signaling Technology), and pp70S6K Thr421/Ser424 (1:1000; Cell Signaling Technology). Quantification was performed using ImageJ software.

In situ hybridization. The Mbp probe (GenBank accession number: NM_001025251.2) was generated from adult mouse brain cDNA using primers 5' -ACACACAAGAACTACCCACTACGG-3' and 5' -AGCTAAA TCTGCTGAGGGACAG- $3^{\prime}$. The $M b p$ fragment was then subcloned into pGEM-T easy vector (Promega) and linearized by restriction digestion. Digoxigenin-labeled riboprobes were synthesized by in vitro transcription with T7 or SP6 polymerase (Roche Applied Science). The in situ hybridization procedure was performed as previously described (Domowicz et al., 2008). Briefly, adult mouse brain sections were postfixed with $4 \%$ PFA for $15 \mathrm{~min}$, followed by riboprobe incubation overnight at $55^{\circ} \mathrm{C}$ in hybridization buffer ( $50 \%$ formamide, $5 \times$ SSC, $1 \%$ SDS, $500 \mu \mathrm{g} / \mathrm{ml}$ tRNA, and $200 \mu \mathrm{g} / \mathrm{ml}$ heparin). Sense probe hybridization was performed as negative control. Posthybridization washes were performed at $65^{\circ} \mathrm{C}$ in solution X ( $50 \%$ formamide, $2 \times \mathrm{SSC}$, and $1 \%$ SDS). Samples were then blocked with lamb serum for $1 \mathrm{~h}$ and incubated with antidigoxigenin antibody conjugated with alkaline phosphatase (Roche Applied Science) for $2 \mathrm{~h}$. Incubation with NBT/BCIP (Roche Applied Science) was used to visualize the RNA duplexes. Select slides were briefly stained with $0.1 \%$ cresyl violet acetate for $3 \mathrm{~min}$ to visualize cell bodies.

Quantitative RT-PCR. The lesioned area of corpus callosum was carefully microdissected using a dissecting microscope and stored at $-80^{\circ} \mathrm{C}$ until extraction. Total RNA was isolated using TRIzol reagent (Invitrogen) followed by RNeasy clean-up kit (Qiagen). RNA (3 $\mu \mathrm{g})$ was reverse transcribed to cDNA using SuperScript III First-Strand Synthesis System for RT-PCR (Invitrogen). Quantitative PCR was performed on an Applied Biosystems Step One Plus Real-Time PCR system. PCR was performed with 
A

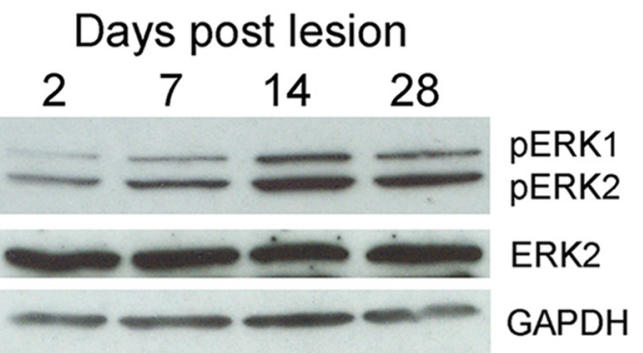

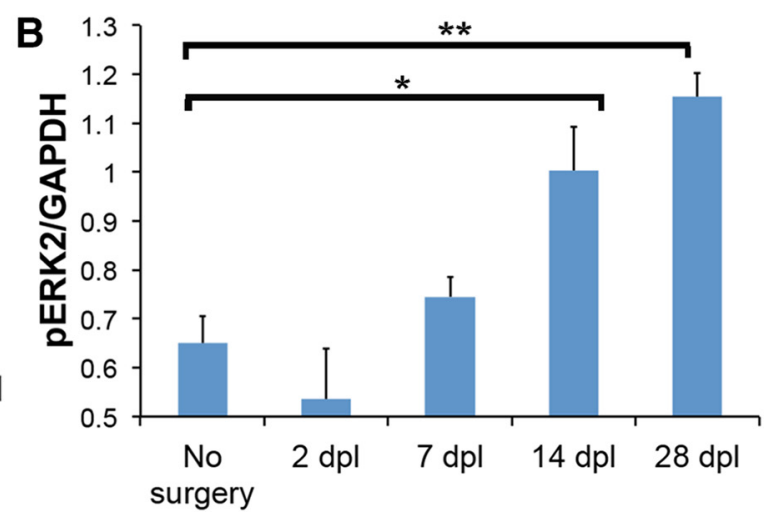

C
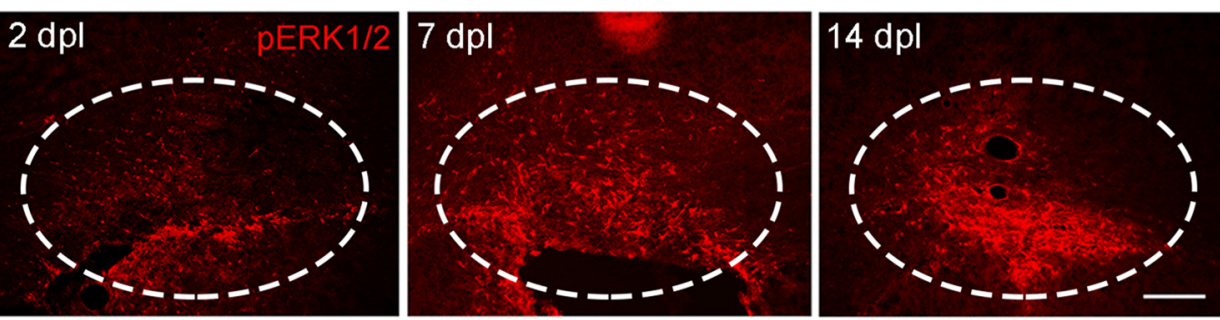

D
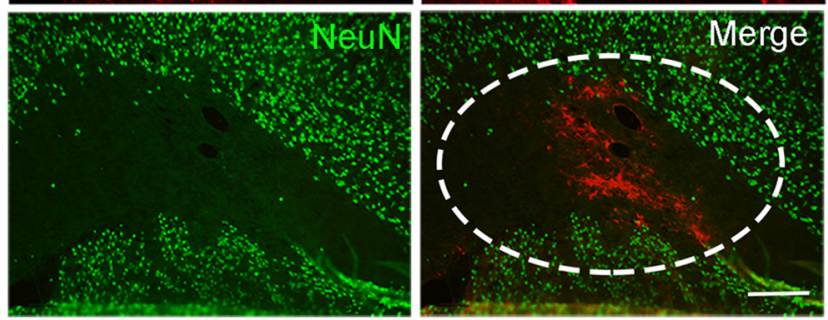

E
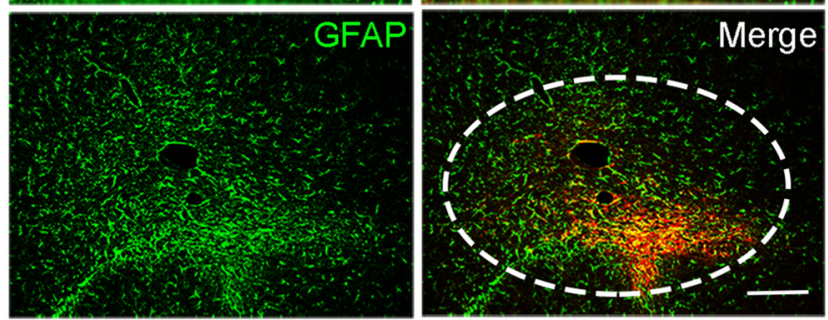

$\mathbf{F}$
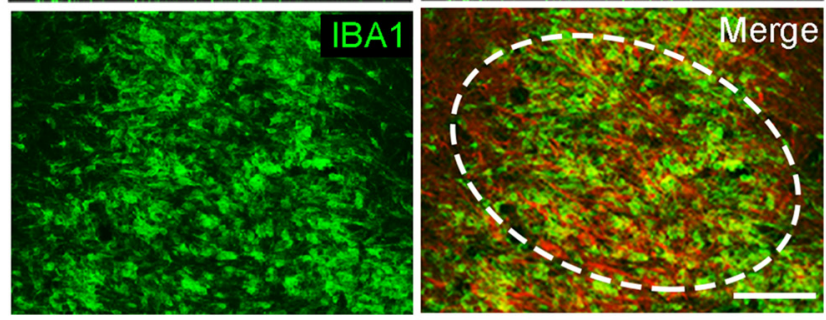

G
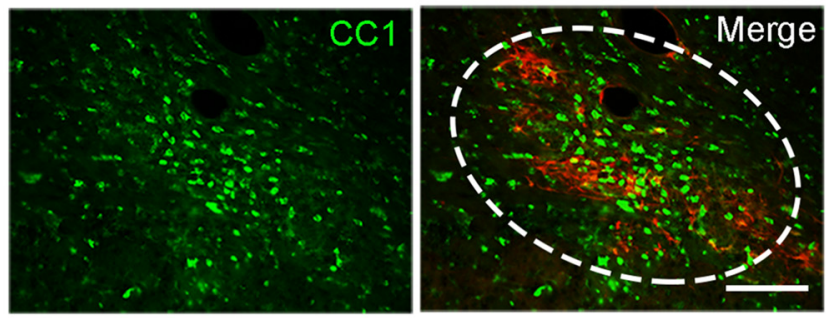

H

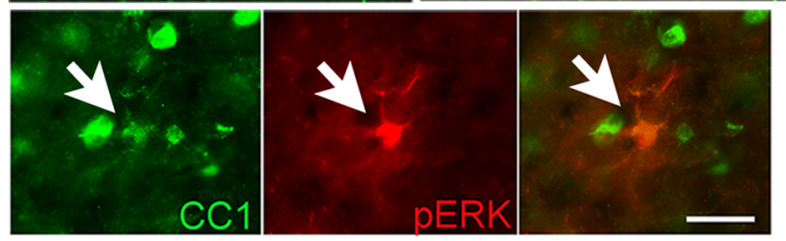


TaqMan Gene Expression Probe Mix with the following RNA-specific primers: Mbp, Mm01266402_m1; Plp1, Mm00456892_m1; Olig1, Mm00497537_s1; Myrf, Mm01194959_m1; Gapdh, Mm99999915_g1 (Life Technologies) and $20 \mathrm{ng}$ of cDNA per reaction. All standard curve reactions and samples were run in triplicate along with no template control reactions for all primer sets. PCR cycling parameters followed manufacturer's recommendations.

Isolation of polysome-bound mRNA. Isolation of polysome-bound mRNA was performed as previously described (del Prete et al., 2007). Briefly, the lesioned area of corpus callosum $(\sim 20 \mu \mathrm{g})$ was carefully microdissected at $7 \mathrm{dpl}$, frozen under liquid nitrogen, and pulverized with mortar and pestle. The sample was lysed with fresh lysis buffer supplemented with RNasin (Promega) and VRC (New England BioLabs) to protect mRNA and the sample was centrifuged briefly to remove nuclei. The supernatant was then supplemented with extraction buffer $[0.2$ м Tris- $\mathrm{HCl}, 0.3 \mathrm{M} \mathrm{NaCl}, 150 \mu \mathrm{g} / \mathrm{ml}$ cycloheximide (Sigma-Aldrich), 650 $\mu \mathrm{g} / \mathrm{ml}$ heparin (Sigma-Aldrich), $10 \mathrm{~mm}$ phenyl-methyl-sulfonyl fluoride (Thermo Fisher Scientific)] to block translation elongation. Mitochondria and membranous debris were then removed via centrifugation. The supernatant was layered onto a $10 \mathrm{ml}$ linear sucrose gradient [15-40\% sucrose $[\mathrm{w} / \mathrm{v}]$, supplemented with cycloheximide (Sigma-Aldrich) and heparin (Sigma-Aldrich) ] and centrifuged for $120 \mathrm{~min}$ at 38,000 rpm at $4^{\circ} \mathrm{C}$ with the brake off. Twenty fractions of $550 \mu \mathrm{l}$ were collected and digested with proteinase $\mathrm{K}$ (Thermo Fisher Scientific). RNAs were recovered by extraction with phenol-chloroform-isoamyl alcohol (SigmaAldrich) followed by ethanol precipitation. Absorbance values at $260 \mathrm{~nm}$ were determined for each sample. To prevent inhibition of the reverse transcriptase as a result of residual heparin, samples were next precipitated with $\mathrm{LiCl}$ (Ambion) before being reverse transcribed. Fractions 1 and 2 were combined for sample 1 ; fractions 3 , 4 , and 5 were combined for sample 2; fractions 6-10 combined for sample 3; fractions $11-15$ for sample 4; and fractions 16-20 for sample 5. Since the amount of RNA is different in each fraction, potentially resulting in efficiency differences of the reverse transcriptase, the RNA amounts were equalized by adding an appropriate amount of luciferase RNA (Promega) to give a final amount of $500 \mathrm{ng}$ of RNA for each sample for cDNA synthesis. After synthesis of the cDNA using SuperScript III First-Strand Synthesis System for RTPCR (Invitrogen), Mbp was amplified from each sample using semiquantitative PCR using the following primers: $5^{\prime}$-ACACACAAGAACTAC CCACTACGG- $3^{\prime}$ and $5^{\prime}$-AGCTAAATCTGCTGAGGGACAG- ${ }^{\prime}$. Band intensity was quantified using ImageJ software and the amount of $M b p$ in each sample was presented as a percentage of the total $M b p$ for that mouse. $N=2$ from each genotype.

Statistical analysis. Statistical analysis was performed using the Student's $t$ test or by one-way ANOVA for Figure 1 and two-way ANOVA for Figure 7 with Tukey's post hoc analysis. Statistical significance was considered for $p<0.05$.

\section{Results}

Increased levels of pERK1/2 are found during active remyelination in the adult mouse corpus callosum

To determine whether ERK MAP kinase signaling plays a role during remyelination, we induced a focal area of demyelination in the corpus callosum of wild-type C57BL/6 adult mice using a

\footnotetext{
Figure 1. ERK1/2 is activated in glial cells following LPC-induced demyelinating injury. $\boldsymbol{A}, \boldsymbol{B}$, Western blot analysis and quantification of microdissected tissue from the lesioned area of corpus callosum from WT mice at 2, 7, 14, and $28 \mathrm{dpl}$. Quantification was performed using ImageJ software ( $n=3$ mice per time point). C, Lesioned tissue from corpus callosum was immunostained for $p E R K 1 / 2$ at 2,7, and $14 \mathrm{dpl}$. Double labeling at $14 \mathrm{dpl}$ for pERK1/2 with NeuN was used to mark neuronal nuclei $(\boldsymbol{D})$, with GFAP to mark astrocytes $(\boldsymbol{E})$, with IBA1 to mark macrophages and microglia $(\boldsymbol{F})$, and with $\mathrm{C}(1$ to mark mature oligodendrocytes $(\boldsymbol{G})$. $\boldsymbol{H}$, Higher power magnification shows colocalization of pERK1/2 in some, but not all, $\mathrm{CC} 1+$ oligodendrocytes at $14 \mathrm{dpl}$. Dashed lines highlight lesioned area. White arrow points to an oligodendrocyteexpressing $\mathrm{pERK} 1 / 2$ inside the lesion. Values are expressed as $\pm \mathrm{SEM},{ }^{*} p \leq 0.05,{ }^{* *} p \leq 0.01$. Scale bars: $\mathbf{C}-\mathbf{G}, 100 \mu \mathrm{m} ; \boldsymbol{H}, 12.5 \mu \mathrm{m}$
}

stereotaxic injection of the glial toxin LPC, and then followed the expression of activated ERK1/2 (pERK1/2) throughout the repair process. This particular model of demyelination was chosen because it enables temporal separation of the processes of demyelination and remyelination and the repair process follows a highly predictable time course (Jeffery and Blakemore, 1995; Blakemore and Franklin, 2008). Tissue from the demyelinated area of corpus callosum was microdissected and analyzed by Western blot at 2, 7,14 , and $28 \mathrm{dpl}$, which are time points corresponding to key steps in the remyelination process: OPC proliferation and migration into the lesioned area, OPC differentiation, and the generation of new myelin sheaths (Nait-Oumesmar et al., 1999). Upregulation of pERK1/2 was first noted at $7 \mathrm{dpl}$ and became statistically significant at 14 and $28 \mathrm{dpl}$, time points that correspond to when new OLs are generating myelin sheaths in response to the demyelinating injury (Fig. $1 A, B$ ). Immunolabeling of cells in the lesioned area confirmed significant upregulation of pERK1/2 at both 7 and $14 \mathrm{dpl}$ (Fig. 1C). To identify the cell types that responded to the demyelinating injury by activating ERK1/2, double labeling was performed using antibodies directed against NeuN to mark neurons (Fig. 1D), GFAP to mark astrocytes (Fig. $1 E$ ), IBA1 to mark macrophages/microglia (Fig. $1 F$ ), and CC1 to mark mature OLs (Fig. 1G,H). OLs, astrocytes, and macrophages/microglia located within the lesioned area expressed pERK1/2, while neuronal cell bodies in the surrounding cortex did not. These data point to a physiologic role for ERK MAP kinase signaling during myelin repair.

\section{Remyelination is delayed when Erk2 is deleted from OLs}

To determine the role of ERK2 during remyelination specifically in cells of the oligodendrocyte lineage, CNP-Cre mice (LappeSiefke et al., 2003) were crossed with mice that carry an Erk2 allele flanked by LoxP sites (Samuels et al., 2008) to create Erk2 CKO mice that lack Erk2 in both OPCs and mature OLs. Double immunolabeling of coronal sections from adult corpus callosum with ERK2 and the mature OL marker CC1 confirmed the specific loss of ERK2 in OLs in Erk2 CKO mice (Fig. 2A). We previously showed that CKO of Erk2 (using either GFAP-Cre or NG2-Cre) results in delayed forebrain myelination that recovers by P21 (Fyffe-Maricich et al., 2011). We confirmed normal levels of myelin in uninjured adult CNP-Cre; Erk2 CKO brain by using the myelin stain LFB and by immunostaining for MBP (Fig. $2 B, C)$. To investigate an OL-specific role for ERK MAP kinase signaling in the repair of demyelinated lesions, LPC was injected into the corpus callosum of adult Erk2 CKO and control littermates to create a focal area of demyelination. Tissue was analyzed at 5, 7, and $21 \mathrm{dpl}$. Serial sections were stained with LFB and the area of demyelination was identified based on a lack of LFB staining (Fig. $2 D, F, H$, boxed area). At $7 \mathrm{dpl}$, a striking twofold increase in the relative lesion volume was noted in Erk2 CKO mice $(n=7)$ compared with control littermates $(n=5 ; p=0.004$; Fig. $2 F, G)$. Larger lesions at $7 \mathrm{dpl}$ could reflect an increased sensitivity of the mutant mice to LPC resulting in larger initial lesion sizes in response to the toxin. Alternatively, early remyelination may be impaired in Erk2 CKO mice. To address these questions, 3DDoctor software was used to reconstruct each lesion and calculate average lesion volumes at each time point during the repair process. The average lesion volume was not significantly different $(p=0.54)$ between control $(n=4)$ and Erk2 CKO littermates $(n=3)$ at $5 \mathrm{dpl}$, demonstrating that ERK2 loss does not influence susceptibility to LPC-induced demyelination (Fig. $2 D, E$ ). Interestingly, by $21 \mathrm{dpl}$, Erk2 CKO $(n=4)$ lesion volumes were no longer significantly different $(p=0.10)$ from control littermates 
A
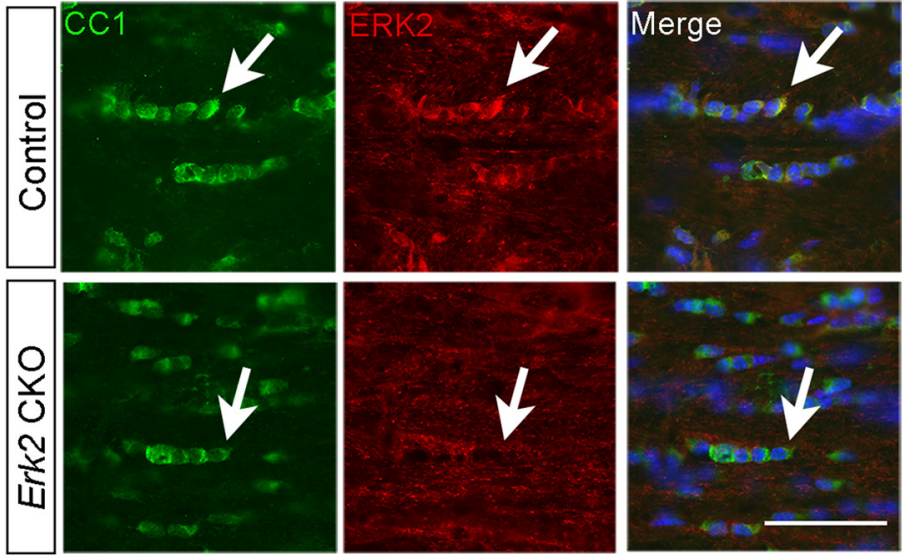

B
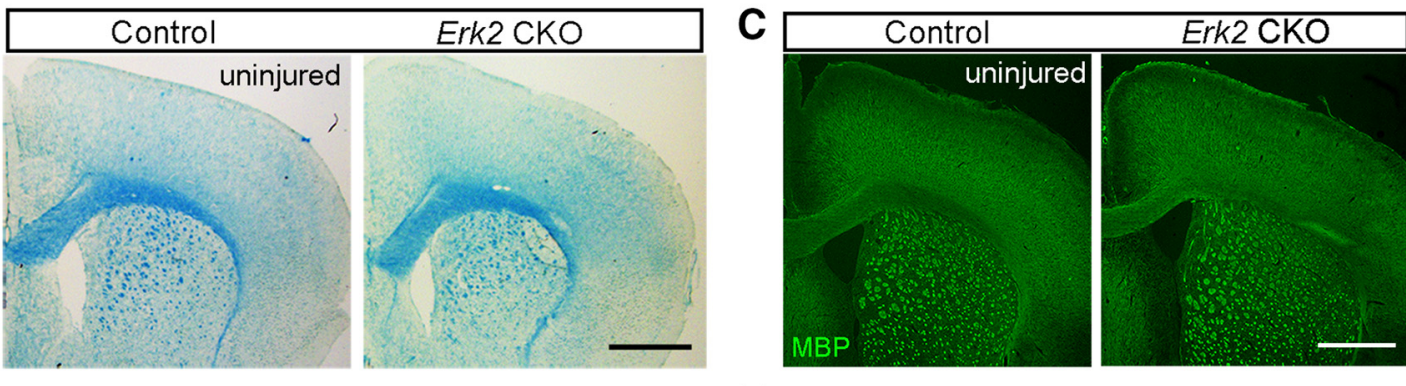

D

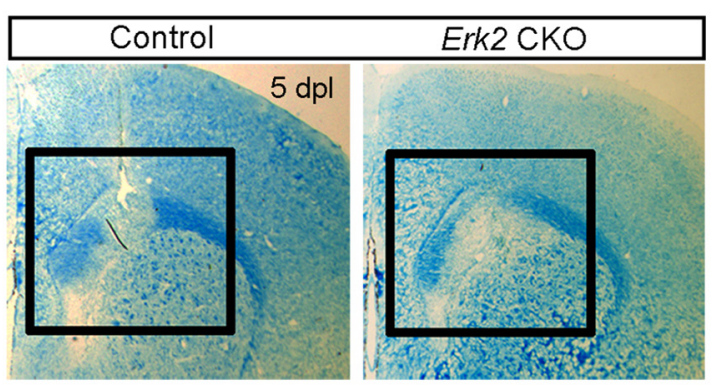

E

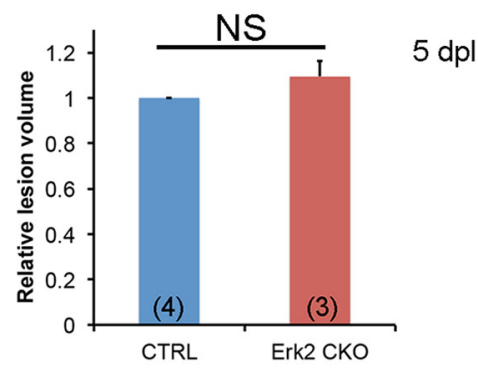

F

$7 \mathrm{dpl}$

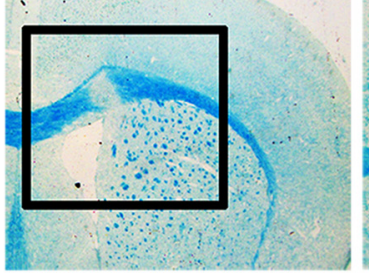

H

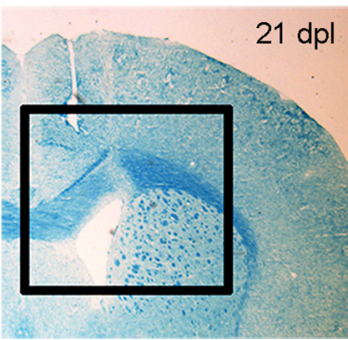

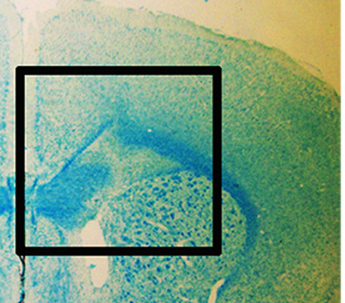

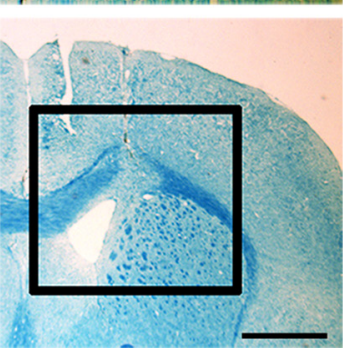

G
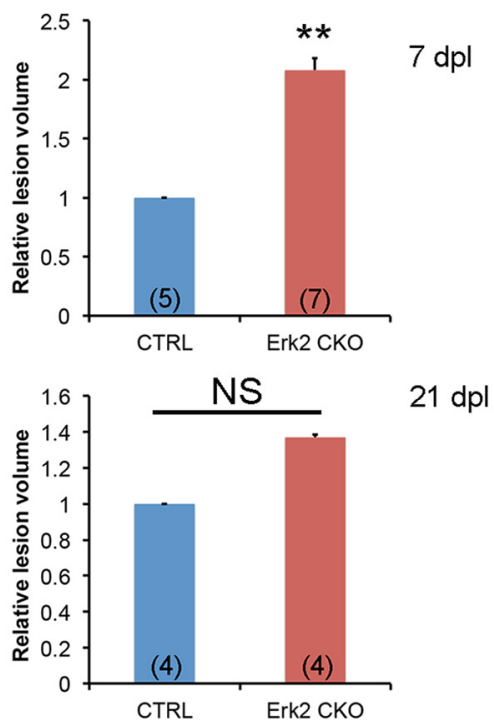

Figure 2. Remyelination is delayed in the absence of ERK2. A, Coronal sections of adult control and Erk2 CKO brain were colabeled with antibodies against CC 1 and ERK2. White arrows highlight ERK2 expression in a string of oligodendrocytes in control mice and a complete lack of ERK2 expression in oligodendrocytes in the Erk2 CKO mice. DAPI marks cell nuclei in blue. LFB staining $(\boldsymbol{B})$ and MBP staining $(\boldsymbol{C})$ demonstrate normal myelination of the corpus callosum in adult uninjured control and Erk2 CKO mice. LFB staining and quantification of the volume of demyelinated corpus callosum using serial sections followed by 3D software reconstruction of control and Erk2 CKO mice at $5 \mathrm{dpl}(n=4$ controls, $n=3$ CKO; $\boldsymbol{D}, \boldsymbol{E}), 7 \mathrm{dpl}(n=5$ controls, $n=7(\mathrm{CK} 0 ; \boldsymbol{F}, \boldsymbol{G})$, and $21 \mathrm{dpl}(n=4$ controls, $n=4$ CKO; $\boldsymbol{H}, \boldsymbol{I})$. Black boxes highlight the lesioned area of the callosum. Values are expressed as \pm SEM, ${ }^{* *} p=0.004$. Scale bars: $\boldsymbol{A}, 50$ $\mu \mathrm{m} ; \boldsymbol{B}-\boldsymbol{D}, \boldsymbol{F}, \boldsymbol{H}, 1 \mathrm{~mm}$. 

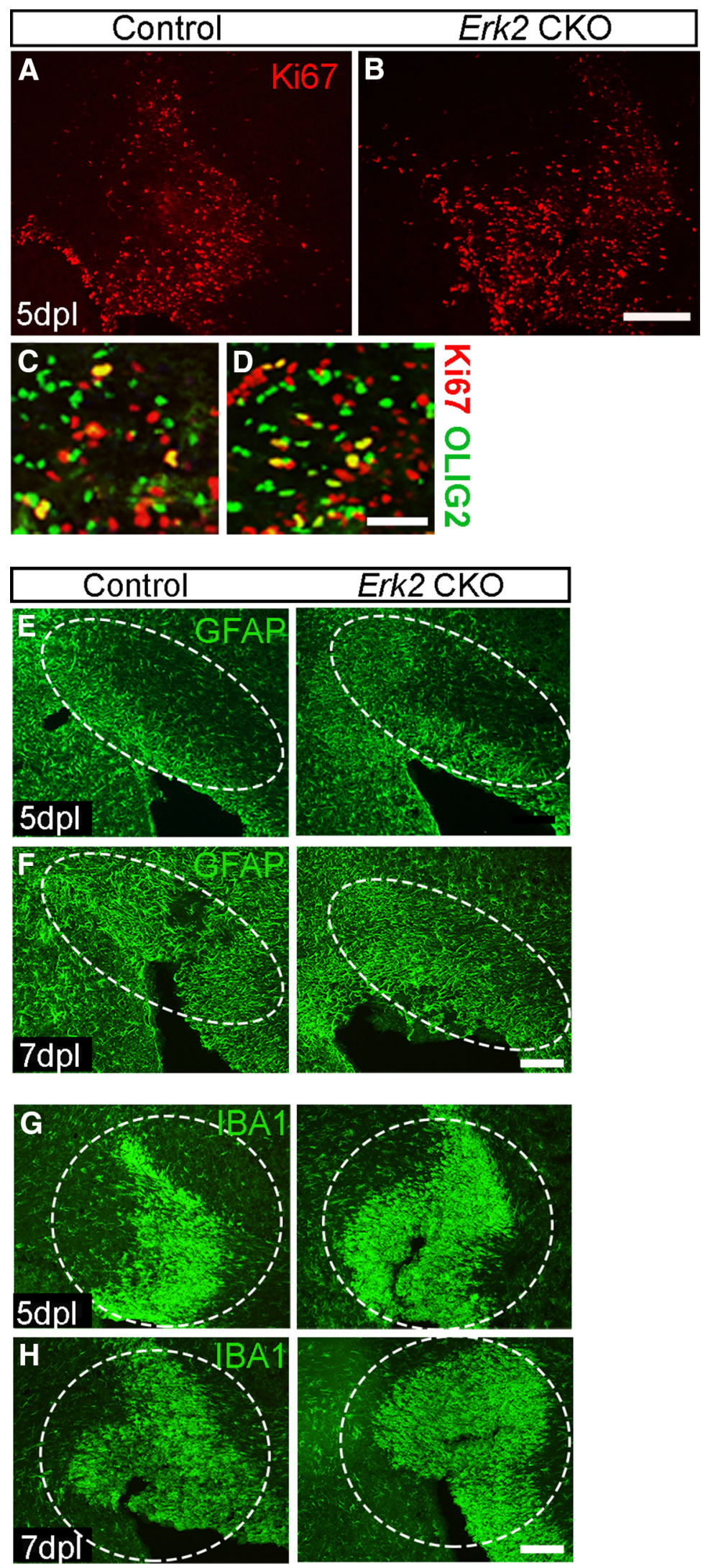

Figure 3. The acute response to demyelination is unaffected by loss of ERK2. Immunostaining for Ki67 shows comparable numbers of proliferating cells inside the demyelinated lesion of control $(\boldsymbol{A})$ and Erk2 CKO mice $(\boldsymbol{B})$ at $5 \mathrm{dpl}$. Double labeling for Ki67 and OLIG2 demonstrates similar numbers of cycling OPCs in control $(\boldsymbol{C})$ and Erk2 CKO (D) mice. Immunostaining with antibodies against GFAP at $5(\boldsymbol{E})$ and $7 \mathrm{dpl}(\boldsymbol{F})$ and IBA1 at $5(\boldsymbol{G})$ and $7 \mathrm{dpl}(\boldsymbol{H})$ shows comparable numbers of astrocytes and microglia/ macrophages inside the lesioned area at both time points from control and Erk2 CKO mice. Scale bars: C, D, $25 \mu \mathrm{m} ; \boldsymbol{A}, \boldsymbol{B}, \boldsymbol{E}-\boldsymbol{H}, 100 \mu \mathrm{m}$. $(n=4)$, demonstrating that over time OLs in the Erk2 CKO mice are able to generate new myelin sheaths (Fig. $2 H, I$ ). Thus, we conclude that in the absence of ERK2, remyelination in the corpus callosum is delayed but not completely inhibited.

The acute response to demyelination is unaffected in Erk2 CKO mice

Although we observed that the initial lesion sizes were similar, important differences in the acute cellular response of the mutant mice to demyelinating injury could result in the observed delay in remyelination. First, we examined whether OPC proliferation and migration into the lesioned area were affected by the loss of ERK2. Double-labeling of the proliferation marker Ki67 and the OPC marker OLIG2 revealed no significant differences in the percentage of OPCs that were proliferating in Erk2 CKO and littermate controls (control $=30 \% \pm 4$, Erk2 $\mathrm{CKO}=28 \% \pm 4, p=0.78 ;>100$ cells were analyzed per animal, $n=5$ mice per genotype) at $5 \mathrm{dpl}$ (Fig. 3A-D). The number of OLIG2 + OPCs found within the lesioned area was also comparable (control $=170 \pm 14$, Erk 2 CKO $=152 \pm 24$, $p=0.53$ ), suggesting that OPC migration and/or survival were similarly unaffected by the absence of ERK2. Reactive astrocytes can negatively affect remyelination by proliferating to form a glial scar around areas of demyelination (Hammond et al., 2014), therefore, we next examined the number of astrocytes in the lesions. Similar numbers of GFAP + astrocytes were seen in and around the lesioned area in both mutant and control mice at 5 and 7 dpl (Fig. 3E,F). Another major component of the remyelination process that can have both positive and negative effects on myelin regeneration is the innate immune response. Immunostaining of lesioned tissue using anti-IBA1 to mark both macrophages and microglia revealed similar infiltration of immune cells in Erk2 CKO mice and control littermates at 5 and $7 \mathrm{dpl}$ (Fig. 3G,H).These data support the conclusion that the initial or acute response to demyelination is unaffected by the deletion of Erk2 from OPCs and OLs.

ERK2 CKO mice have a selective deficit in MBP expression early in the myelin repair process

Blocking the expression of pERK1/2 in cell culture hinders the ability of OPCs to transition to mature OLs (Fyffe-Maricich et al., 2011; Guardiola-Diaz et al., 2012; Dai et al., 2014). In contrast, in vivo exper- 

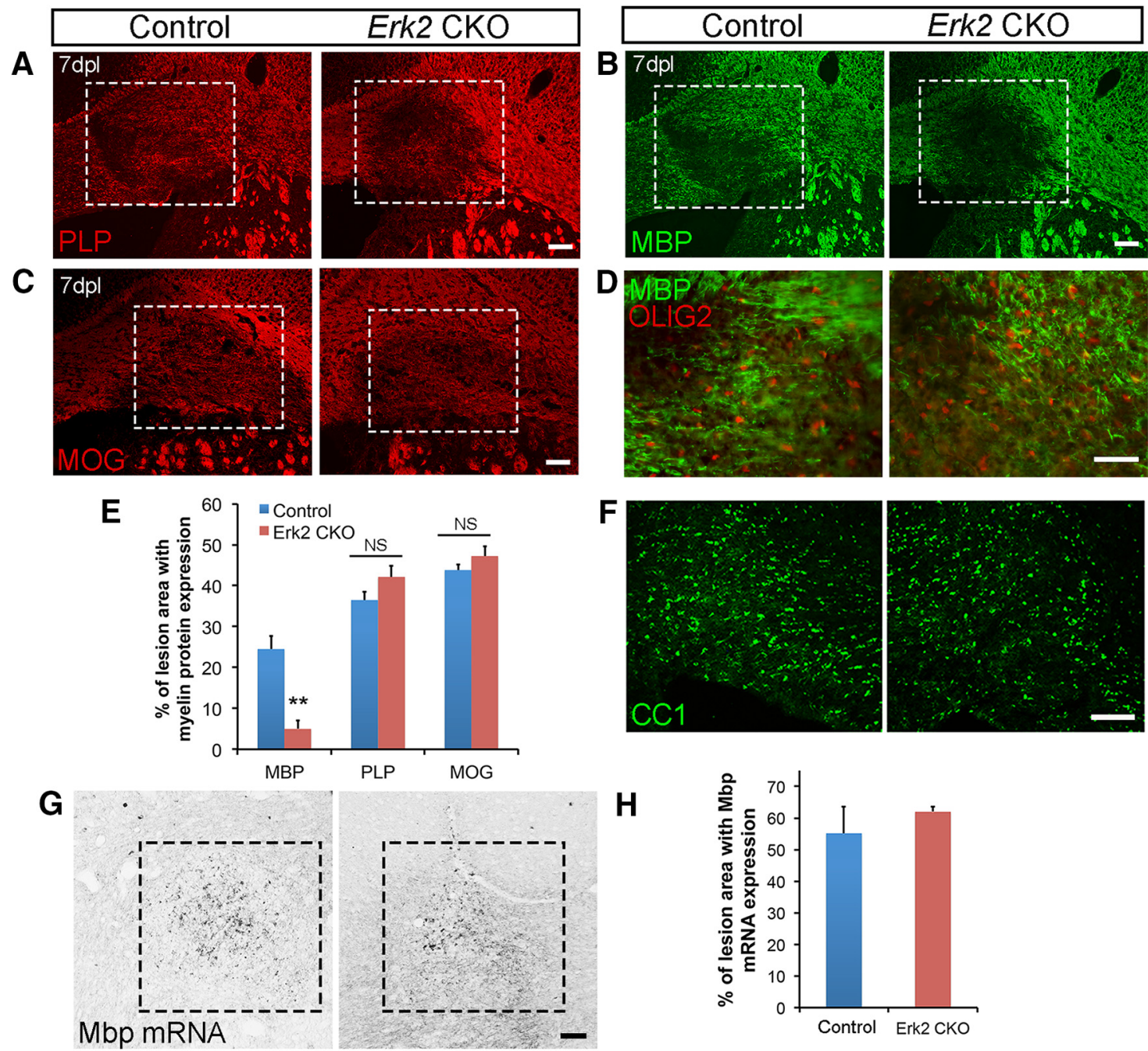

H
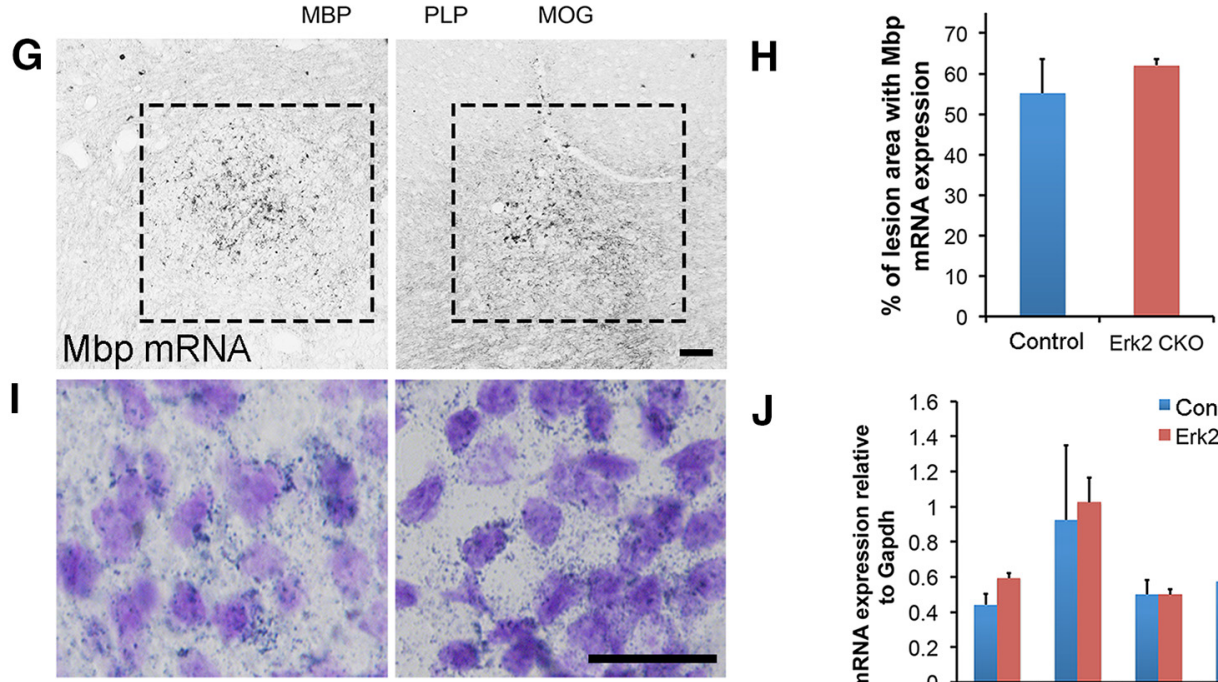

$J$
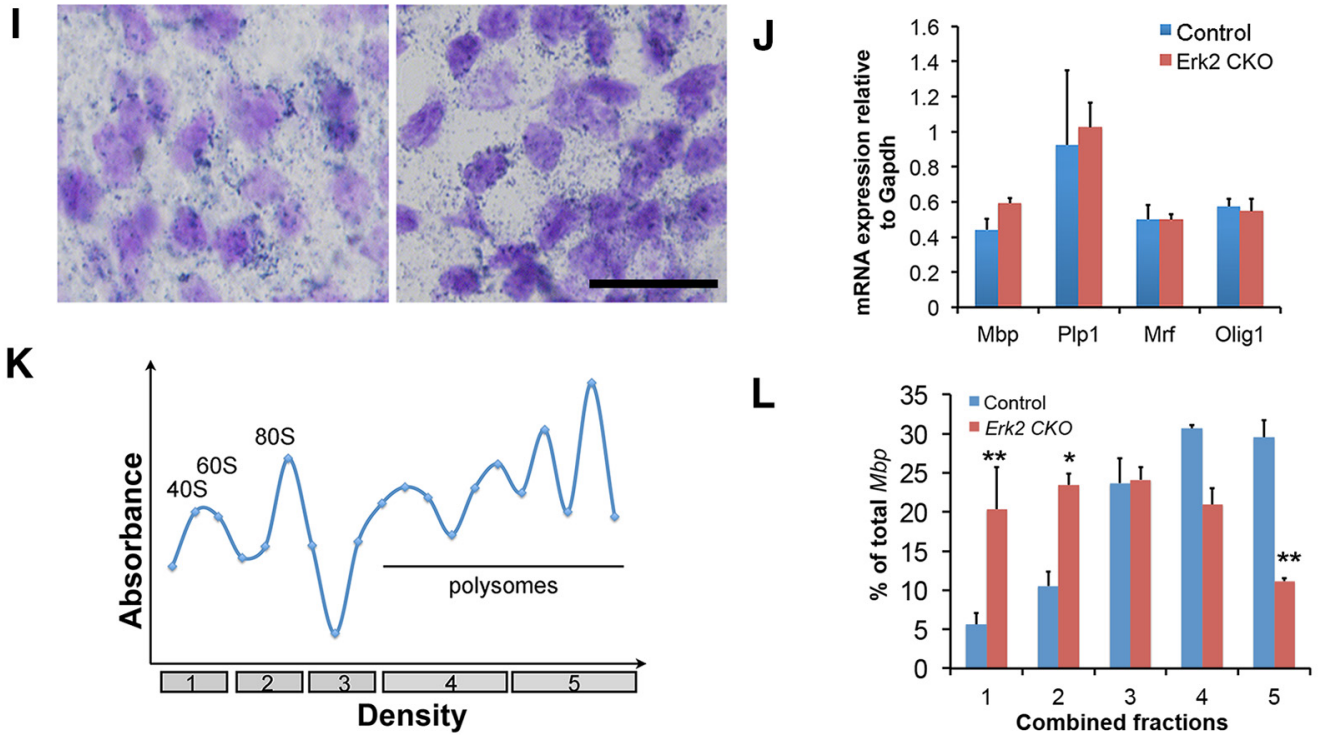

Figure 4. ERK2 is important for the translation of MBP but is dispensable for its transcription during remyelination. Immunostaining with antibodies against PLP $(\boldsymbol{A})$, MBP $(\boldsymbol{B})$, and MOG $(\boldsymbol{C})$ demonstrates a selective deficit in MBP expression in the lesion area of corpus callosum from Erk2 CKO mice at $7 \mathrm{dpl}$ compared with control littermates. D, Colabeling with antibodies against 0LIG2 and MBP along the lesion edge shows appropriate localization of MBP to the $0 \mathrm{~L}$ processes in both control and Erk2 CKO mice. E, Quantification confirms a significant decrease in the percentage of the lesion area containing MBP immunopositivity in the Erk2 CKO mice, while no significant differences between control $(n=4)$ and mutant $(n=3)$ mice were found for PLP or MOG. $F$, Immunostaining demonstrates similar numbers of $\mathrm{CC} 1+0 \mathrm{~L}$ in lesioned corpus callosum from control and Erk2 CKO mice suggesting that OPC differentiation is unaffected. G, In situ hybridization shows comparable levels of Mbp mRNA from control and Erk2 CKO mice at $7 \mathrm{dpl}$. $\boldsymbol{H}$, Quantification demonstrates no significant difference in the percentage of the lesion area containing Mbp mRNA between Erk2 CKO $(n=3)$ and controls $(n=3)$. I, High-resolution imaging of in situ hybridization for Mbp with cresyl violet counterstaining shows proper Mbp mRNA localization in Erk2 CKO mice. J, Quantitative RT-PCR confirms comparable levels of Mbp, Plp, Mrf, and Olig1 mRNA in microdissected lesions from Erk2 CKO and control littermates. $\boldsymbol{K}$, Representative graph showing (Figure legend continues) 
iments have shown that genetic deletion of both Erk1 and Erk2 does not affect OPC differentiation during postnatal development (Ishii et al., 2012). To investigate whether a delay in OPC differentiation in Erk2 CKO mice following demyelinating injury might account for the observed delay in remyelination, we used antibodies against $\mathrm{CC} 1$ to mark the cell bodies of mature OLs at the site of demyelination at $7 \mathrm{dpl}$ in Erk2 CKO and control littermates (Fig. $4 F$ ). We saw no significant difference in the number of CC $1+$ mature OLs (control $=60 \pm 7, \operatorname{Erk} 2 \mathrm{CKO}=51 \pm 4, p=$ 0.34 ) found within the lesioned area, suggesting that ERK2 is dispensable for OPC differentiation during remyelination in adult mice in vivo.

Efficient remyelination depends not only on the proliferation, migration, and differentiation of OPCs to mature OLs, but also requires the expression and targeting of myelin proteins to $\mathrm{OL}$ processes. To further probe the cause of increased lesion sizes in Erk2 CKO mice at $7 \mathrm{dpl}$, we investigated the expression of several myelin proteins. Proteolipid protein (PLP) and MBP are the most abundant myelin proteins in CNS myelin sheaths, while myelin oligodendrocyte glycoprotein (MOG) represents a minor component. Immunostaining of lesioned tissue demonstrated that PLP and MOG were expressed at comparable levels between control and mutant mice (Fig. 4A,C). In contrast, MBP was clearly visible throughout all but the lesion core in control mice, while Erk2 CKO mice showed significantly decreased MBP expression in the lesion at this time point (Fig. 4B). Double immunolabeling with antibodies against OLIG2 and MBP revealed that MBP was appropriately localized to the OL processes in the small number of OLs found to express MBP along the lesion border in the Erk2 CKO mice (Fig. 4D). Quantification of the percentage of lesion area with immunopositive staining confirmed a significant reduction in MBP expression in Erk2 CKO mice (control $=24.5 \%$ \pm 3.3, Erk2 $\mathrm{CKO}=5.0 \% \pm 2.0, p=0.005$; Fig. $4 E$ ).

\section{Loss of ERK2 affects the translation but not the transcription of MBP following demyelination}

We previously showed that OLs lacking both Erk1 and Erk2 have significantly reduced levels of $M b p$ and Plp mRNAs, resulting in hypomyelination during postnatal development (Ishii et al., 2012). To determine whether the decreased expression of MBP seen in Erk2 CKO lesions was the result of a similar defect in transcription, we performed in situ hybridization to analyze $M b p$ mRNA expression throughout the lesioned area of corpus callosum (Fig. 4G). Quantification of the percentage of the lesioned area with $M b p$ mRNA expression revealed no significant differences between control and Erk2 CKO mice at $7 \mathrm{dpl}$ (control = 55.2\% \pm 8.5, Erk2 CKO = 61.9\% $\pm 1.6, p=0.51$; Fig. $4 H$ ). Counterstaining of the in situ slides with cresyl violet enabled the visualization of $M b p$ mRNA localization in relation to the cell body (Fig. 4I). The distribution of Mbp mRNA appeared similar in control and Erk2 CKO mice. Quantitative RT-PCR analysis using mRNA isolated from microdissected tissue from the lesioned area of the corpus callosum confirmed that $M b p$ mRNA levels were not significantly different between Erk2 CKO mice

\section{$\leftarrow$}

(Figure legend continues.) absorbance at $260 \mathrm{~nm}$ from fractions collected following sucrose density fractionation. Boxed areas show the fractions combined to generate the five samples used for RT-PCR. L, Semiquantitative RT-PCR demonstrates that a significantly lower percentage of the total Mbp mRNA was present in sample 5 from Erk2 CKO mice compared with control littermates, while a significantly higher percentage of the total Mbp was present in samples 1 and 2. Dashed lines highlight the lesioned area of the corpus callosum. Values are expressed as \pm SEM, ${ }^{*} p \leq 0.05,{ }^{* *} p \leq 0.01$. Scale bars: $\boldsymbol{D}, 50 \mu \mathrm{m}, I, 20 \mu \mathrm{m}, A-C, F, G, 100 \mu \mathrm{m}$. and control littermates at $7 \mathrm{dpl}$ (Fig. $4 \mathrm{~J}$ ). These data demonstrate that ERK2 is dispensable for the transcription and proper localization of $M b p$ mRNA. Finally, mRNA levels of $P l p$ and two transcription factors important for late-stage OL differentiation/ myelin initiation (myelin gene regulatory factor; Myrf) and for repair of demyelinated lesions (oligodendrocyte transcription factor 1, Olig1) were also found to be similar in control and Erk2 CKO mice at $7 \mathrm{dpl}$ (Fig. 4J). These data show that loss of Erk2, when Erk1 remains functional, does not appear to have a major impact on transcription.

Low levels of MBP protein at $7 \mathrm{dpl}$ in the Erk2 CKO mice could occur as a result of a defect in protein stability or due to an inhibition in translation. When a given mRNA transcript is to be translated, the large 60S ribosomal subunit joins the small $40 \mathrm{~S}$ subunit and an $80 \mathrm{~S}$ translational-competent monosome is formed. Since more than one $80 \mathrm{~S}$ monosome can translate an mRNA at the same time resulting in the formation of polysomes, the number of polysomes on an mRNA can be used as a measure of the translatability of a particular transcript (Warner et al., 1963; Mašek et al., 2011). To compare the amount of MBP translation in Erk2 CKO and control littermates at $7 \mathrm{dpl}$, we used velocity sedimentation to separate $M b p$ mRNA associated with monosomes (relatively low mass) from translationally active polysomes (relatively high mass; del Prete et al., 2007). The lesioned area of the corpus callosum was microdissected from Erk2 $\mathrm{CKO}$ and control littermates and cells were exposed to cycloheximide to block translation elongation by stalling or "freezing" $80 \mathrm{~S}$ ribosomes on mRNAs. Velocity sedimentation of cellular extracts in sucrose gradients separated monosomes (which segregate in early fractions) from polysomes (found in late fractions) and RNA was purified from each of the 20 fractions that were collected. Absorbance at $260 \mathrm{~nm}$ values was plotted for each fraction allowing visualization of peaks corresponding to RNA associated with monosomes compared with polysomes (Fig. $4 K$ ). Fractions were then combined to create five samples for each genotype and semiquantitative RT-PCR was used to determine the percentage of the total amount of $M b p$ mRNA that was present in each sample. The largest percentage of $M b p$ transcripts from the control mice were found in the heavy sucrose fractions (samples 4 and 5) suggesting that they were likely bound to a large number of ribosomes. In contrast, a significantly higher percentage of the total $M b p$ mRNA was present in the early fractions (samples 1 and 2) from the Erk2 CKO mice compared with controls [Sample 1 (control $=5.64 \% \pm 1.4$, Erk2 CKO $=20.34 \% \pm 5.4, p=$ 0.008 ), Sample 2 (control $=10.52 \% \pm 1.58$, Erk $2 \mathrm{CKO}=23.45 \%$ $\pm 1.43, p=0.02)$ ] demonstrating a reduced association with ribosomes indicating inhibited MBP translation in the absence of ERK2 (Fig. 4L). These data suggest that the critical role for ERK2 in remyelination is to allow the efficient and timely translation of MBP.

\section{ERK2 regulates the activation of $\mathrm{S6}$ ribosomal protein}

Next, we sought to determine a potential mechanism for the translational inhibition observed in Erk2 CKO mice during myelin repair. The ribosomal protein S6 (S6RP) is one of 30 distinct ribosomal proteins which, together with $18 \mathrm{~S}$ rRNA, constitute the smaller 40S ribosomal subunit (Chan and Wool, 1988). S6RP plays a critical role in ribosome function and protein translation and is a known downstream target of both the PI3K/Akt/mTOR and MEK/ERK pathways in several different cell types (Shi et al., 2002; Lehman et al., 2003). To assess whether the activation of ERK2 is required for S6RP phosphorylation specifically in OLs in the context of myelin repair, we quantified the expression of 
A

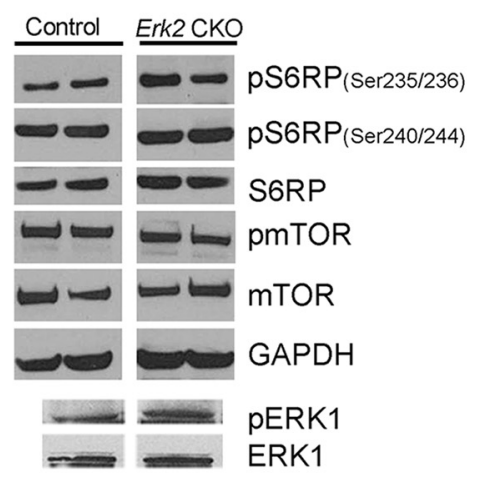

B

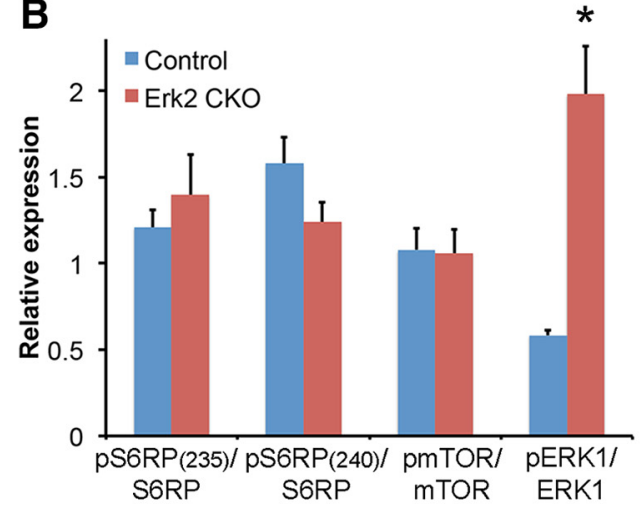

C
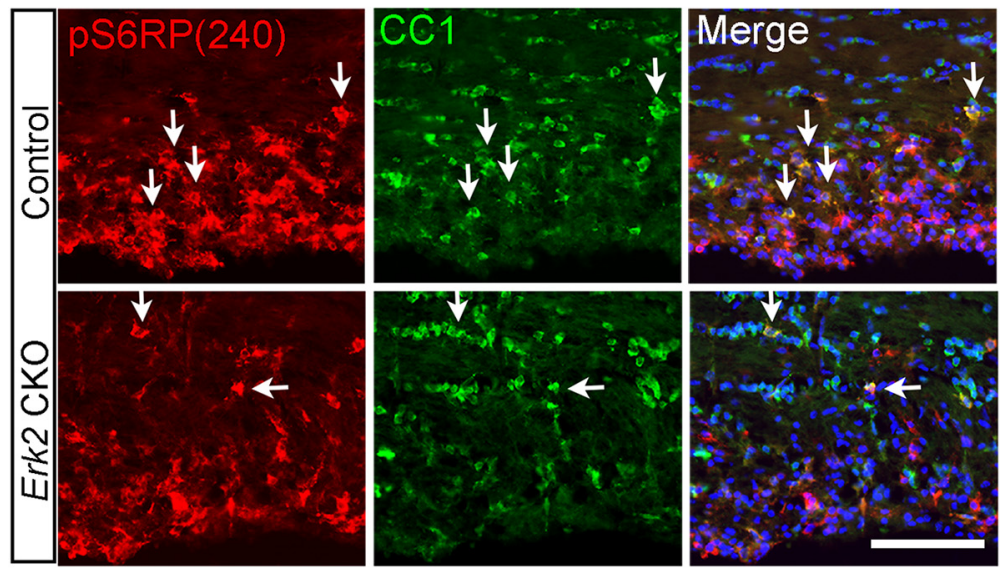

D

E
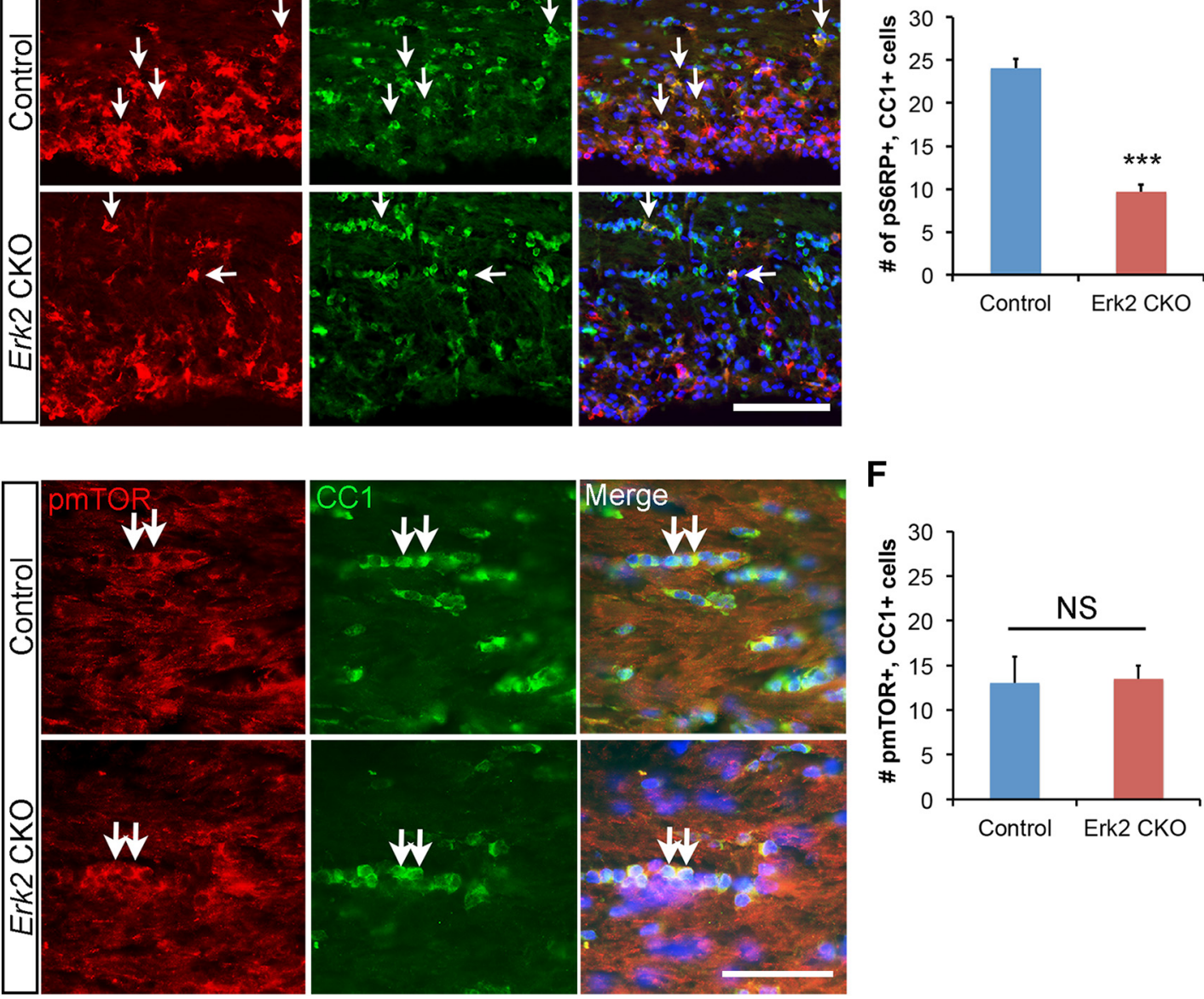

$\mathbf{F}$

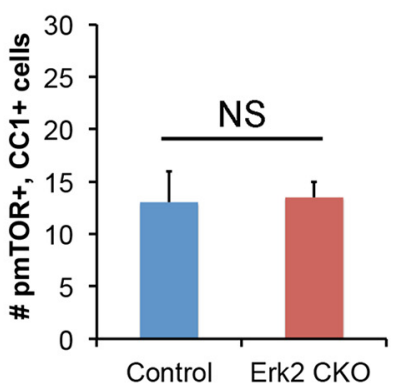

Figure 5. Oligodendrocyte-specific loss of Erk2 leads to decreased expression of pS6RP during remyelination. Western blot analysis of microdissected lesioned tissue at $7 \mathrm{dpl}(\boldsymbol{A})$ followed by quantification ( $n=4$ of each genotype; $\boldsymbol{B}$ ) demonstrates a significant increase in pERK1 relative to total ERK1 in Erk2 CKO mice compared with littermate controls. $\boldsymbol{C}$, Immunostaining using antibodies against pS6RP at Ser240/244 [pS6RP(240)] and CC1 to mark 0Ls followed by quantification of the number of double-labeled cells inside the lesioned area (D) demonstrated a significant decrease in the number of double-labeled cells in Erk2 CKO mice $(n=6)$ compared with control littermates $(n=6)$ at $7 \mathrm{dpl}$. $\boldsymbol{E}$, Colabeling of pmTOR at Ser2448 and CC 1 to mark $0 \mathrm{Ls}$ followed by quantification $(\boldsymbol{F})$ showed similar numbers of double-labeled cells in Erk2 CKO lesions compared with control littermates at $7 \mathrm{dpl}$. White arrows highlight double-labeled cells. DAPI marks cell nuclei in blue. Values are expressed as \pm SEM, ${ }^{*} p \leq 0.05,{ }^{* * *} p \leq 0.0001$. Scale bars: $C, 100 \mu \mathrm{m} ; \boldsymbol{E}, 50 \mu \mathrm{m}$.

pS6RP by Western blot using microdissected lesioned tissue at 7 $\mathrm{dpl}$ in controls and Erk2 CKO mice. No significant differences were found in the phosphorylation of S6RP relative to total S6RP at Serine $235 / 236[\mathrm{pS6RP}(235)$ (control $=1.21 \pm 0.10$, Erk2 $\mathrm{CKO}=1.39 \pm 0.23, p=0.49)]$; however, we did note decreased phosphorylation of S6RP at Serine 240/244 [pS6RP(240) (control $=1.58 \pm 0.15$, Erk $2 \mathrm{CKO}=1.24 \pm 0.12)]$ although these results were subtle and did not reach statistical significance $(p=$
0.12; Fig. $5 A, B)$. Since pS6RP is expressed in many cell types within the lesion, it is possible that changes in S6RP phosphorylation occurring specifically in OLs (the only cells that lack ERK2 in this experiment) might go undetected. To address this possibility, we colabeled lesioned tissue with antibodies directed against pS6RP and CC1. We observed a significant decrease in the number of OLs within the lesioned area expressing pS6RP(240) $\left(\right.$ control $=24 \pm 1.02$, Erk $2 \mathrm{CKO}=10 \pm 0.79, p=9.63 \times 10^{-7}$; 
$n=6$ mice per genotype; Fig. $5 C, D)$. Only one or two $\mathrm{pS} 6 \mathrm{RP}(235)+\mathrm{CC} 1+$ cells were consistently observed within the lesioned area from either control or Erk2 CKO mice, suggesting that phosphorylation at this particular site may be quite transient or may play a more minor role in oligodendrocytes at this time point post injury. Since S6RP is a well known target of the mechanistic target of rapamycin (mTOR), we next sought to determine whether decreased mTOR activation might occur in the Erk2 CKO mice due to cross talk between the two signaling pathways. No significant decreases in mTOR expression or activation (pmTOR Ser2448) were found by Western blot in the Erk2 CKO mice at $7 \mathrm{dpl}$ (Fig. 5A,B). Double immunostaining of tissue sections with antibodies directed against pmTOR(2448) and CC1 confirmed these findings. Similar numbers of pmTOR + OLs were found inside the lesioned area from control and Erk2 CKO mice at $7 \mathrm{dpl}$ (control $=13 \pm 4.24$, Erk $2 \mathrm{CKO}=13.5 \pm 2.12, p=$ 0.899 ; Fig. $5 E, F)$. Although these data show that the deletion of Erk2 does not directly affect the phosphorylation of mTOR itself, it remains possible that the loss of ERK2 negatively impacts mTOR signaling through effects on the activation of other components of the mTORC1 complex. In striking contrast to the decreases found in $\operatorname{pS6RP}(240)$, a 3.4-fold increase in activated ERK1 (pERK1) was present at $7 \mathrm{dpl}$ in Erk2 CKO mice (control = $0.58 \pm 0.03$, Erk2 CKO $=1.98 \pm 0.28, p=0.03$; Fig. $5 A, B)$. The defect in S6RP phosphorylation at $7 \mathrm{dpl}$, despite a large increase in pERK1 in Erk2 CKO mice, suggests an isoform-specific role for ERK2 in the control of protein translation during this early stage of remyelination.

\section{ERK2 is required for activation of the S6RP upstream kinase p70S6K}

We next sought to determine how ERK2 might regulate the activation of S6RP. Two main classes of protein kinases phosphorylate S6RP: the p70 S6 ribosomal protein kinases (p70S6K1/2) and the p90 ribosomal S6 kinase (RSK) family (Hauge and Frödin, 2006; Wood et al., 2013). To enhance protein translation, activated p70S6K (pp70S6K) phosphorylates S6RP at five Serine residues (Ser 235/236/240/244/247), while RSK phosphorylates S6RP exclusively at Ser235/236 (Ferrari et al., 1991; Pende et al., 2004; Roux et al., 2007). The Akt/mTOR pathway is classically thought of as the regulator of p70S6K activation in many cell types including OLs, while the MEK/ERK pathway activates RSK (Wood et al., 2013; Lebrun-Julien et al., 2014). Importantly, the MEK/ERK pathway has also been shown to regulate p70S6K in both cancer and hematopoietic cells (Lehman et al., 2003; Guégan et al., 2014). Because we found very few $\operatorname{pS6RP}(235)+$, $\mathrm{CC} 1+$ double-labeled cells in both Erk2 CKO and control mice, suggesting minimal involvement of RSK at $7 \mathrm{dpl}$, and we saw significantly decreased pS6RP(240) expression specifically in Erk2 CKO mice, we hypothesized that ERK2 is required for the activation of p70S6K in OLs at the onset of remyelination. p70S6K requires phosphorylation at multiple sites to achieve full activation. Phosphorylation at Thr421 and Ser424 is thought to activate p70S6K via relief of pseudosubstrate suppression, while phosphorylation at Thr389 within the linker domain most closely correlates with p70S6K activity in vivo (Pullen and Thomas, 1997; Weng et al., 1998). The MEK/ERK pathway has been shown to phosphorylate p70S6K at both Thr421/Ser424 and Thr389 in other cell types (Shi et al., 2002). Western blot analysis of microdissected lesioned tissue from the corpus callosum at $7 \mathrm{dpl}$ demonstrated a significant decrease in the phosphorylation of $\mathrm{p} 70 \mathrm{~S} 6 \mathrm{~K}$ at Thr389 and Thr421/Ser424 in Erk2 CKO mice (Fig. 6A,B). Double labeling for pp70S6K Thr421/Ser424 [pp70S6K(421)] and CC1 followed by cell counts confirmed a significant decrease in pp70S6K (421) in OLs (control $=42 \pm 1.5$, Erk2 CKO $=21 \pm 4.7$, $p=0.037$; Fig. $6 C, D$ ). These data demonstrate that loss of signaling through ERK2 in OLs leads to an overall decrease in the activation of p70S6K during remyelination.

\section{Recovery of p70S6K and S6RP phosphorylation correlates with the normalization of MBP expression at $14 \mathrm{dpl}$ in Erk2 CKO mice}

LFB staining and lesion size quantification suggested that remyelination in Erk2 CKO mice recovered by $21 \mathrm{dpl}$ (Fig. $2 \mathrm{H}, \mathrm{I}$ ), so we next examined whether restoration of MBP expression a week earlier at $14 \mathrm{dpl} \mathrm{might} \mathrm{account} \mathrm{for} \mathrm{the} \mathrm{eventual} \mathrm{recovery} \mathrm{of} \mathrm{myelin}$ repair. Immunostaining of lesioned tissue followed by quantification revealed that MBP expression was comparable between Erk2 CKO mice and littermate controls at $14 \mathrm{dpl}$ (Fig. 7 A,B). Next, we sought to determine whether the recovery in MBP expression might correlate with an upregulation in phosphorylation of S6RP and p70S6K in the Erk2 CKO mice, suggesting that over time compensation from another pathway may allow for sufficient activation of the translational machinery to release the block in MBP translation. Sections were colabeled with antibodies directed against pS6RP(240) or pp70S6K(421) and CC1 and double-labeled cells were counted from the area of the lesion. Uninjured tissue from the contralateral side of the corpus callosum was similarly analyzed to determine whether baseline differences in the phosphorylation of these proteins exist as a result of the Erk2 deletion. No significant difference in the percentage of $\mathrm{CC} 1+$ OLs expressing pp70S6K $(421)$ (control $=89.6 \% \pm 3.7$, Erk2 CKO $=75.8 \% \pm 2.9, p=0.18$ ) remained in the lesioned area of Erk2 CKO mice at $14 \mathrm{dpl}$ (Fig. 7C,D). Similarly, no significant differences were observed between Erk2 CKO and control littermates in uninjured tissue (control $=25.4 \% \pm 2.2$, Erk2 $\mathrm{CKO}=24.8 \% \pm 2.8, p=0.99)$. Importantly, pp70S6K(421) expression was dramatically increased in the Erk2 CKO at $14 \mathrm{dpl}$ $($ Erk $2 \mathrm{CKO}=75.8 \% \pm 2.9)$ compared with $7 \mathrm{dpl}($ Erk2 $\mathrm{CKO}=$ $21.9 \% \pm 3.0, p<0.0001)$ suggesting that this increased level of activation may allow for adequate phosphorylation of downstream targets. In support of this conclusion, no significant differences were found in the percentage of CC1+ OLs expressing $\operatorname{pS6RP}(240)$ in lesioned tissue at $14 \mathrm{dpl}$ (control $=20.5 \% \pm 1.9$, Erk $2 \mathrm{CKO}=17.2 \% \pm 1.0, p=0.72)$ and $\mathrm{pS} 6 \mathrm{RP}(240)$ expression was significantly increased in Erk2 CKO mice at $14 \mathrm{dpl}$ (Erk2 $\mathrm{CKO}=17.2 \% \pm 1.0)$ compared with7 $\mathrm{dpl}($ Erk $2 \mathrm{CKO}=7.4 \% \pm$ $1.7, p=0.004$; Fig. $7 E, F)$. Similar to pp70S6K(421), analysis of uninjured tissue did not detect any baseline differences in pS6RP (240) between control and Erk2 CKO mice suggesting that the role for ERK2 in the phosphorylation of these proteins may be specific to either the injured environment or to an environment where the myelination program has been activated.

Since the AKT/mTOR pathway is a known regulator of p70S6K, we next looked to see whether the dramatic recovery in p70S6K phosphorylation in the Erk2 CKO mice at $14 \mathrm{dpl} \mathrm{might}$ occur as a result of compensation through increased levels of pmTOR. Tissue sections were colabeled with antibodies directed against pmTOR and CC1 and double-labeled cells were counted. No significant differences were found in the percentage of $\mathrm{CC} 1+$ OLs expressing pmTOR in lesioned tissue from control and Erk2 CKO mice at $14 \mathrm{dpl}($ control $=28.8 \% \pm 4.1$, Erk $2 \mathrm{CKO}=30.9 \% \pm$ 5.7, $p=0.78)$.

In contrast to both p70S6K and S6RP, baseline differences in pERK1 expression were detected between control and Erk2 CKO mice. Since the phospho-specific antibody recognizes the same 
A

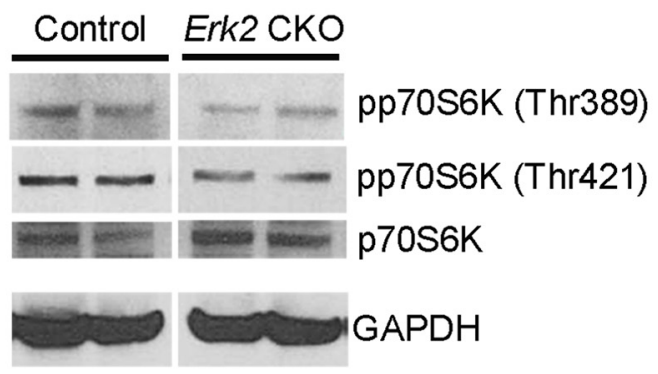

C
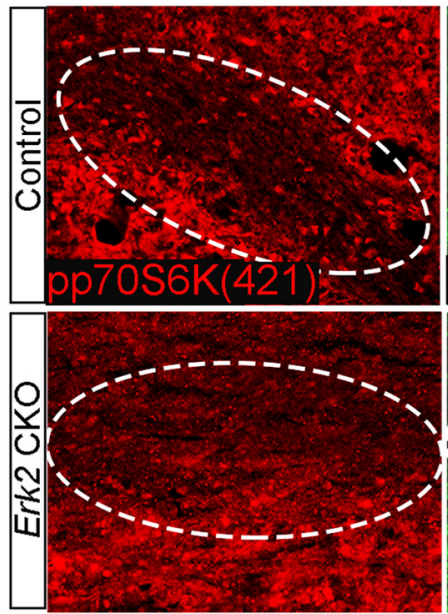

D

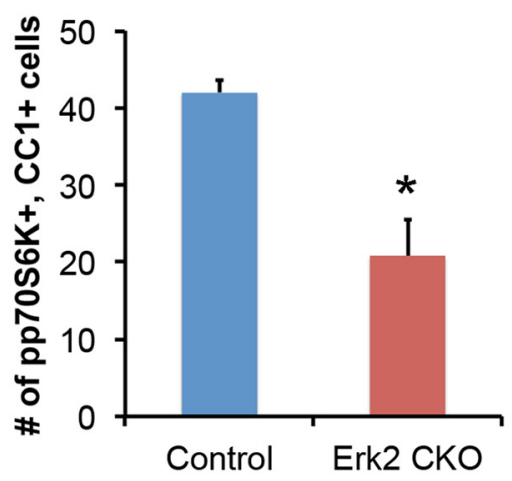

E
B

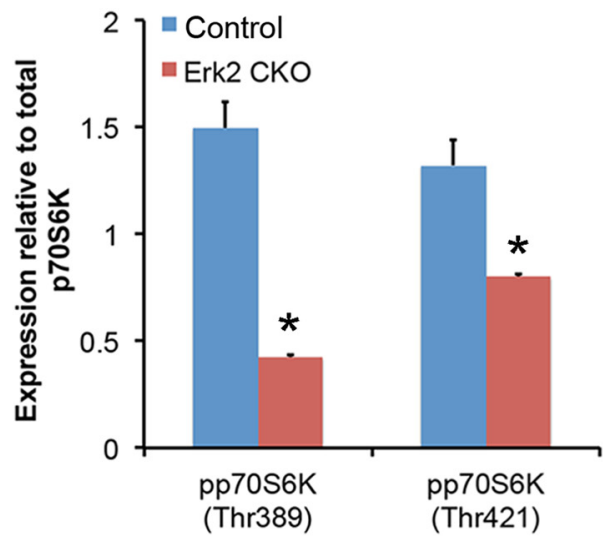

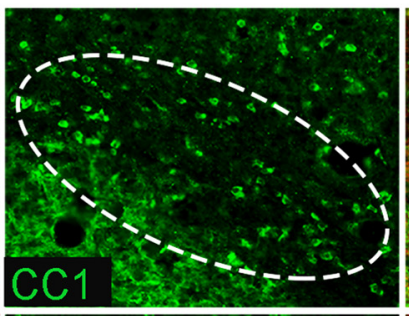
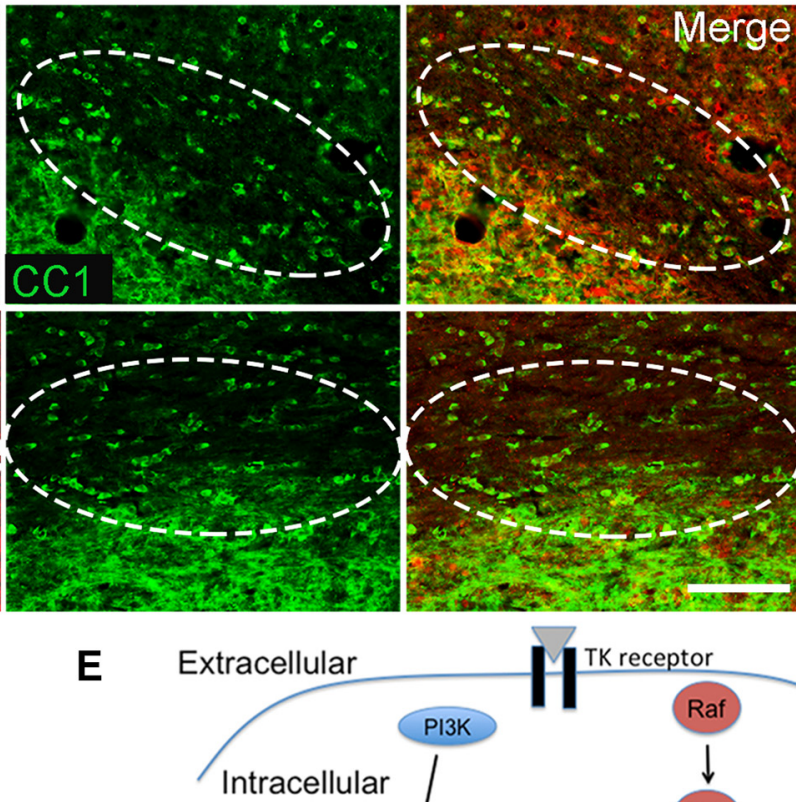

$$
\text { 而 }
$$
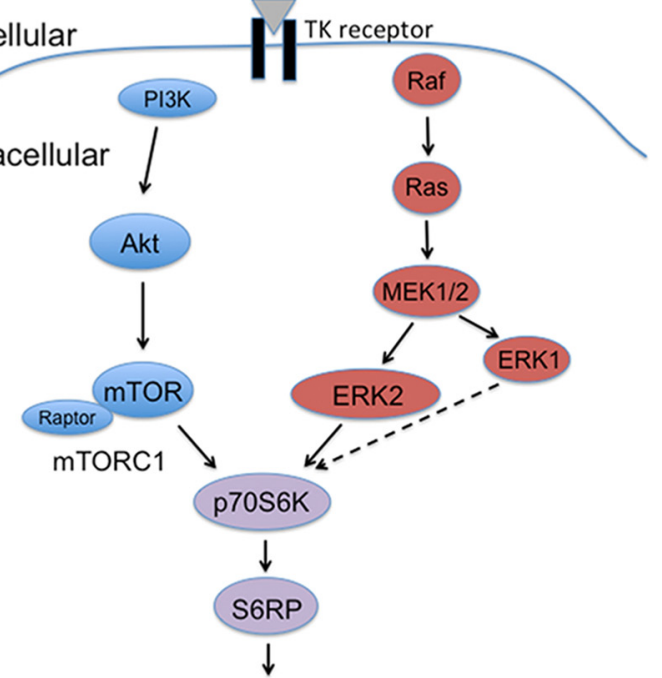

Local translation of MBP

Figure 6. ERK2 is necessary for the complete activation of the ribosomal p7056 kinase in OLs at a critical time point during myelin repair. Western blot analysis of microdissected lesioned tissue from Erk2 CKO and control littermates at $7 \mathrm{dpl}(\boldsymbol{A})$ followed by quantification $(\boldsymbol{B})$ demonstrates a significant decrease in the phosphorylation of the p70S6K at Thr389 and Thr421/Ser424 relative to total p70S6K in Erk2 CKO mice. C, Immunostaining of lesioned tissue at 7 dpl followed by cell counts (D) demonstrates a significant decrease in the number of CC1 and pp70S6K Thr421/Ser424 colabeled cells in the Erk2 CKO mice. Dashed lines highlight cells along the border of the lesioned area. $E$, A schematic representation of our working model showing convergence of Akt/mTOR and MEK/ERK pathways to regulate the onset of remyelination. Values are expressed as \pm SEM, ${ }^{*} p \leq 0.05$. Scale bar, $100 \mu \mathrm{m}$.

site on both ERK1 and ERK2, we were not able to examine individual expression levels for these two phosphorylated proteins in the control mice. In the Erk2 CKO mice, however, OLs lack ERK2 so the pERK1/2 antibody will give a readout solely of pERK1 expression. Semiquantitative analysis of the fluorescence intensity in individual CC1 + cells demonstrated significant upregulation of pERK in both control and Erk2 CKO mice at $7 \mathrm{dpl}$ compared with uninjured tissue (Fig. $7 \mathrm{H}$ ). Equivalent total pERK expression was seen in mutant and control mice at all time points (uninjured, $p=0.98 ; 7 \mathrm{dpl}, p=0.95 ; 14 \mathrm{dpl}, p=0.80$; Fig. 7H). These data show that the level of pERK1 expression alone in Erk2 CKO mice is comparable to the total combined intensity of pERK1 and pERK2 in OLs from control mice, providing strong support for a specific role for pERK2 in the control of MBP trans- 
A

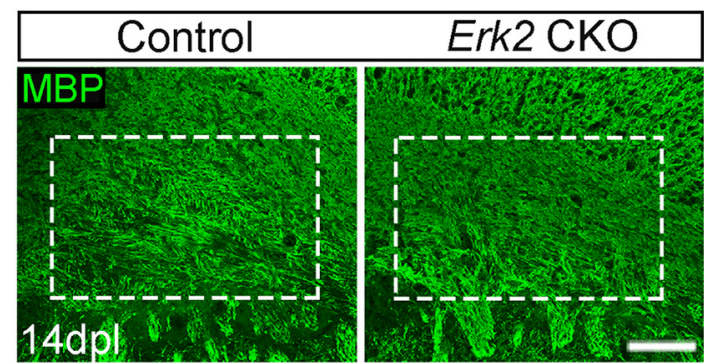

C

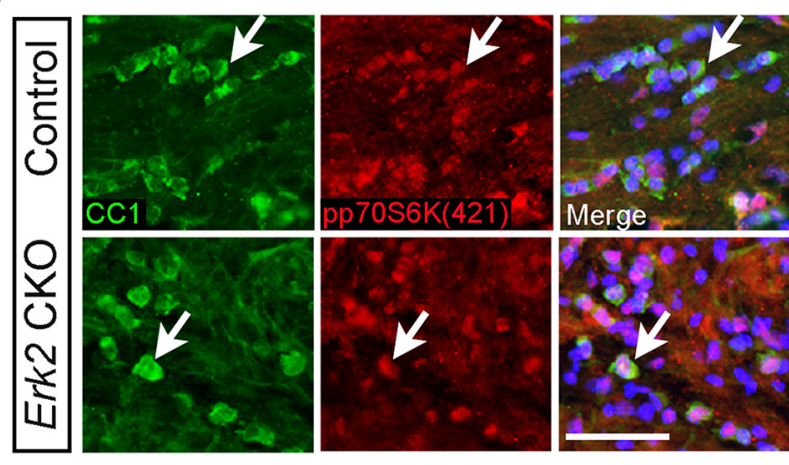

$\mathbf{E}$

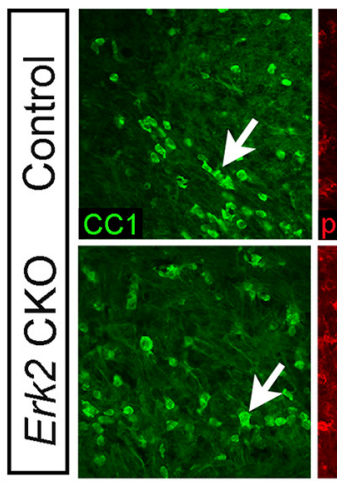

G

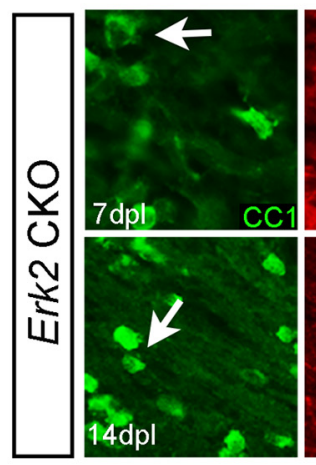

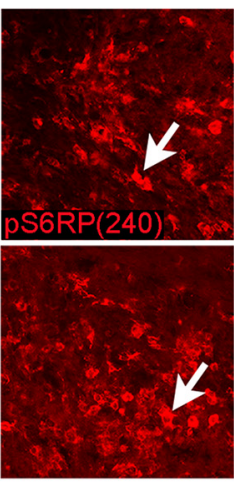
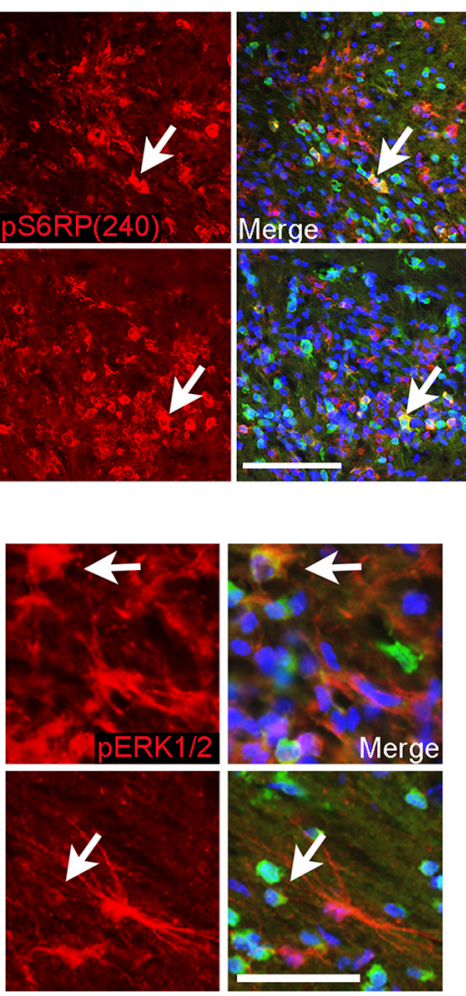

B
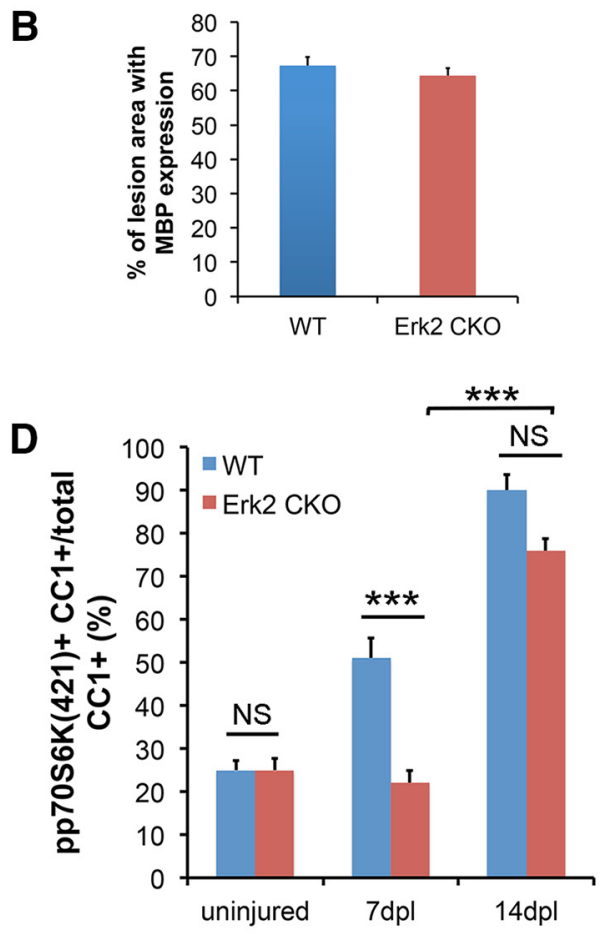

$\mathbf{F}$

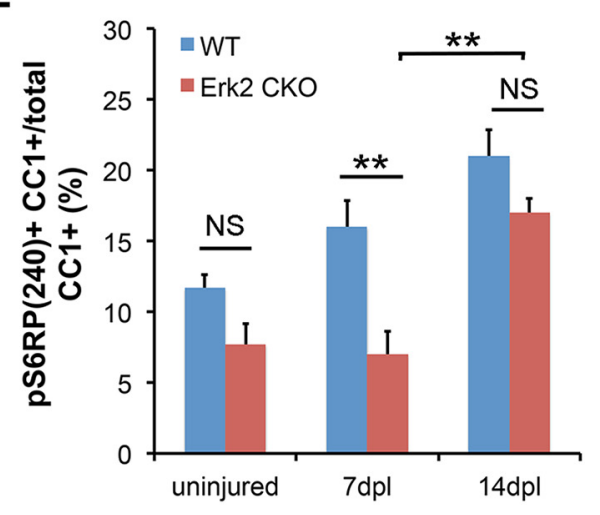

H

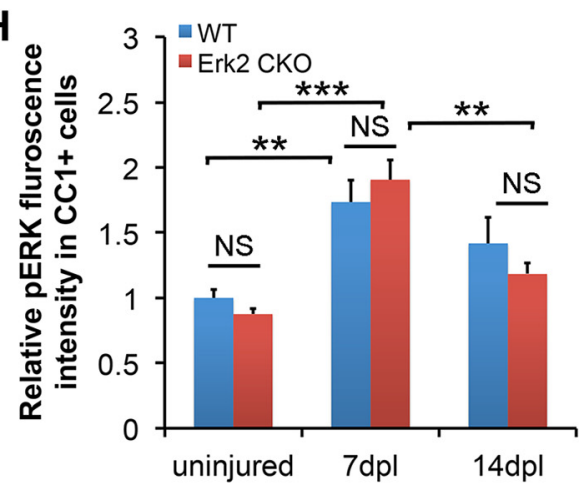

Figure 7. Increased phosphorylation of p70S6K and S6RP and decreased levels of pERK1 correlate with the recovery of MBP expression at $14 \mathrm{dpl}$ in Erk2 CKO mice. $A$, Immunostaining for MBP at $14 \mathrm{dpl}$ demonstrates recovery in MBP protein expression in Erk2 CKO mice. $B$, Quantification confirms no significant difference in the percentage of the lesion area containing MBP immunopositivity in the Erk2 $\mathrm{CK} 0$ mice compared with control littermates at $14 \mathrm{dpl}$. C, Immunostaining of lesioned tissue using antibodies against pp70S6K(421) and (C 1 at $14 \mathrm{dpl}$. D, Quantification of the percentage of $\mathrm{CC} 1+0 \mathrm{Ls}$ expressing pp70S6K(421) in Erk2 CK0 and controls in uninjured tissue at 7 and at $14 \mathrm{dpl}$. $\boldsymbol{E}$, Colabeling of lesioned tissue at $14 \mathrm{dpl}$ for $C(1$ and pS6RP(240). $\boldsymbol{F}$, Quantification shows no significant difference in the percentage of CC1 + OLs that express pS6RP(240) in the Erk2 CKO mice compared with control littermates in uninjured tissue. The percentage of $C C 1+0 \mathrm{Ls}$ expressing pS6RP(240) was significantly decreased in Erk2 CK0 mice at $7 \mathrm{dpl}$ but reached control levels by $14 \mathrm{dpl}$. G, Immunostaining of lesioned tissue from Erk2 CKO mice using antibodies against pERK1/2 and CC 1 demonstrates a robust decrease in pERK1 expression specifically in $C(1+$ cells (white arrows) between 7 and $14 \mathrm{dpl}$. $\boldsymbol{H}$, Quantification of pERK fluorescence intensity confirms comparable levels of total pERK in control and Erk2 CKO mice at all time points analyzed despite deletion of the ERK2 isoform suggesting a massive upregulation of pERK1. Dashed lines highlight lesioned area. DAPI marks cell nuclei in blue. White arrows highlight double-labeled cells. Values are expressed as \pm SEM, ${ }^{*} p \leq 0.05,{ }^{* *} p \leq 0.01,{ }^{* * *} p \leq 0.001$. Scale bars: $A, \boldsymbol{E}, 100 \mu \mathrm{m} ; \boldsymbol{C}, \mathbf{G}, 50 \mu \mathrm{m}$. 
lation that cannot be compensated for by pERK1. Furthermore, since the expression of pERK1 drops significantly in Erk2 CKO OLs between 7 and $14 \mathrm{dpl}(p=0.009$; Fig. $7 G, H)$, correlating with the recovery of $\mathrm{S} 6 \mathrm{RP}(240)$ phosphorylation and MBP protein expression, high levels of pERK1 in the absence of ERK2 may in fact be detrimental.

\section{Discussion}

Our data demonstrate a critical role for ERK2 in the translational control of MBP, a myelin protein critical for the production of myelin sheaths, during remyelination in the adult brain. Previous studies have implicated the ERK pathway in myelination both in vitro and in vivo during development (Bhat and Zhang, 1996; Du et al., 2006; Galabova-Kovacs et al., 2008; Younes-Rapozo et al., 2009; Fyffe-Maricich et al., 2011; Furusho et al., 2012; GuardiolaDiaz et al., 2012; Ishii et al., 2012, 2013; J. Xiao et al., 2012; Dai et al., 2014) and following demyelination (Sun et al., 2012; L. Xiao et al., 2012; Fyffe-Maricich et al., 2013); however, the molecular mechanisms and downstream targets have remained poorly defined. Here, we show that loss of Erk2 in adult OPCs leads to a delay in the expression of MBP following demyelinating injury to the corpus callosum, similar to its role in developmental myelination. We also provide evidence for a downstream mechanism involving p70S6K and S6RP activation that is necessary for the timely translation of MBP, but appears dispensable for the expression of other myelin proteins. It is particularly intriguing that early remyelination was inhibited simply due to lack of MBP protein. This is consistent, however, with previous myelin gene deletion mouse mutants: deletion of MAG, PLP, or CNP has very little impact on the production of myelin itself, although longterm detrimental effects on axonal function clearly occur (Li et al., 1994; Griffiths et al., 1998; Lappe-Siefke et al., 2003). In contrast, shiverer mice, which have a deletion in the MBP gene, produce essentially no myelin, illuminating the critical nature of this specific myelin protein (Roach et al., 1985; Molineaux et al., 1986).

Recently, sustained activation of ERK MAP kinase signaling in Schwann cells (the myelinating cells of the peripheral nervous system) was shown to result in minor changes in transcript levels while large-scale changes in protein production led to massive hypermyelination (Sheean et al., 2014). Here, we show for the first time that ERK2 exerts translational control of MBP production following demyelinating injury in the CNS in the absence of changes in mRNA levels. Unlike most myelin protein mRNAs, $M b p$ mRNA is transported within RNA granules that contain all of the necessary molecules for its translation from the nucleus to the distal OL processes, where it is translated locally at the axonglial contact site (Colman et al., 1982; Barbarese et al., 1995). Myelin-associated oligodendrocyte basic protein, carbonic anhydrase II, tau, and APP mRNAs are also localized to distal OL processes (Ghandour and Skoff, 1991; LoPresti et al., 1995; Holz et al., 1996; Garcia-Ladona et al., 1997). It is conceivable that ERK2 regulates the translation of multiple locally translated $\mathrm{mR}$ NAs in OLs, thus promoting their rapid and efficient translation in the setting of remyelination; future studies will directly address this question. In support of this hypothesis, ERK signaling has been shown to regulate local protein synthesis in response to neuronal activity in hippocampal neurons; a role that is critical for long-lasting forms of synaptic plasticity and memory (Kelleher et al., 2004).

In the developing CNS, mTOR inhibition causes decreased MBP expression along with decreased pS6RP (Tyler et al., 2009; Bercury et al., 2014; Dai et al., 2014; Lebrun-Julien et al., 2014; Wahl et al., 2014). Interestingly, MBP is the only myelin protein for which a specific translational defect occurs following conditional deletion of the mTORC1 complex in OLs (Bercury et al., 2014; Lebrun-Julien et al., 2014). Several studies have proposed working models depicting possible signaling mechanisms involving both Akt/mTOR and ERK1/2 signaling pathways to control myelination (Bibollet-Bahena and Almazan, 2009; Bercury et al., 2014; Dai et al., 2014; Wahl et al., 2014). We propose a model where the Akt/mTOR and MEK/ERK pathways converge at the level of p70S6K activation, with each pathway independently sufficient for a basal level of p70S6K activation and subsequent MBP translation (Fig. 6E). However, maximal efficiency and thus the appropriate timing of $\mathrm{MBP}$ expression during remyelination require a critical threshold that is achieved only through coordinated activation of both pathways. In the absence of ERK2, sufficient activation of p70S6K is eventually reached as a result of phosphorylation by other kinases, enabling the translation of $\mathrm{MBP}$ and remyelination to occur after a short delay. Our results illuminate a potential molecular mechanism through which ERK2 MAP kinase signaling regulates the onset of remyelination following demyelinating injury. In support of our model, both ERK and PI3K/Akt/mTOR pathways are required for optimal p70S6K activity in cancer and hematopoietic cells, where phosphorylation of $\mathrm{p} 70 \mathrm{~S} 6 \mathrm{~K}$ at Thr389 appears to be regulated by both ERK and mTOR pathways while phosphorylation at Thr421/ Ser424 appears to be modulated by ERK MAP kinase signaling alone (Shi et al., 2002; Lehman et al., 2003; Guégan et al., 2014). It has been proposed that phosphorylation at Thr421/Ser424 by ERK1/2 allows access to Thr389 by other kinases such as mTOR, resulting in optimal p70S6K activity and providing a mechanism where both Akt/mTOR and ERK MAP kinase signaling are needed in cooperation to achieve full activation of $\mathrm{p} 70 \mathrm{~S} 6 \mathrm{~K}$.

Although MBP was the only protein for which defects in translation were reported in this study, it is possible that ERK2 controls protein translation on a larger scale. p70S6K targets a number of proteins in addition to S6RP that are important for translation. For example, p70S6K impacts the initiation step of translation by phosphorylating the cap-binding complex component eIF4B (Raught et al., 2004), and it controls the elongation step by inactivating the eukaryotic Elongation Factor-2 kinase (Wang et al., 2001). Comprehensive large-scale proteomic studies are underway to determine whether protein translation may be impacted on a more broad level throughout the process of myelin repair in Erk2 CKO mice. It is also possible that the loss of Erk2 leads to the delayed translation of MBP as a result of additional and/or alternative mechanisms. The potential involvement of other molecules known to be critical for MBP translation, at least during development, should be considered. Fyn tyrosine kinase plays a central role in the translational regulation of $\mathrm{MBP}$ at sites of axon-glial contact (White et al., 2008; Laursen et al., 2009, 2011; Wake et al., 2011; White et al., 2012). Fyn activation results in a breakdown of the RNA granule, releasing $M b p$ mRNA from its inhibitors allowing localized translation to ensue. Interestingly, a recent study demonstrated that Fyn kinase activation promoted a transient increase in the phosphorylation of ERK1/2 (Pérez et al., 2013). It is possible that ERK2 is downstream of Fyn, suggesting that ERK2 may be an important part of the axontailored synthesis machinery and that these two important kinases may work together to ensure the timely expression of MBP needed for the rapid expansion of the OL membrane.

Erk1/2 double knock-out (Erk1/2 dKO) mice initially express $\mathrm{MBP}$ protein on schedule, although once they reach the second postnatal week both MBP mRNA and protein levels are dramatically reduced (Ishii et al., 2012). If ERK2 is critical for the onset of 
MBP translation, then how is it that Erk1/2 dKO mice are able to express MBP without delay? First, it is possible that ERK2's role in developmental myelination differs from its role in the context of myelin repair in the adult. This is unlikely, since Erk2 CKO mice show delayed MBP expression in the forebrain at P10 (FyffeMaricich et al., 2011). Alternatively, in the absence of both Erk1 and Erk2, other similar kinases are likely able to compensate and synergize with mTORC1 so that a critical threshold of p70S6K phosphorylation is reached. When only Erk2 is deleted, ERK1 likely competes for the activation of $\mathrm{p} 70 \mathrm{~S} 6 \mathrm{~K}$. In vitro phosphorylation assays show that pERK1 can phosphorylate p70S6K at Thr421/Ser424, but it does so with poor efficiency compared with pERK2 (Shi et al., 2002). We hypothesize that the 3.5-fold increase in pERK1 that occurs in Erk2 CKO mice at $7 \mathrm{dpl}$ (Fig. $5 A, B)$ functions in a dominant-negative fashion to inhibit the timely and complete activation of p70S6K, resulting in decreased MBP translation and slower remyelination. Consistent with this hypothesis, we show that the decrease in pERK1 that occurs between 7 and $14 \mathrm{dpl}$ in the Erk2 CKO mice coincides with the recovery of S6RP phosphorylation and MBP expression (Fig. 7).

The delay in MBP translation seen in the Erk2 CKO mice, although significant, was only transient (Figs. 2E, 4H). The concept of "timing" is of fundamental importance for the success of remyelination in patients with MS and a window of opportunity appears to exist when OPC differentiation and maturation can successfully occur (Miller and Mi, 2007; Franklin and ffrenchConstant, 2008). This window begins with the expansion of adult OPCs and ends once the lesion environment converts from one of acute inflammation to chronic inflammation (Kotter et al., 2011). Additionally, cell-intrinsic timing limitations exist. Timelapse microscopy of cocultures (Watkins et al., 2008) and in vivo live imaging in zebrafish (Czopka et al., 2013) both demonstrate that individual OLs have only a brief time window, soon after terminal differentiation, in which they are able to form all of their myelin segments. Inhibition of pERK2 in newly differentiated OLs could act as a tipping point to turn an otherwise acute remyelinating lesion into a chronic lesion if the resulting delay in MBP translation causes OLs to miss their "critical window" for new myelin generation. In support of this hypothesis, chronic MS lesions have been found to contain $M b p$ mRNA, but to lack MBP protein (Bauer et al., 2012). It will be important to determine whether defects in ERK MAP kinase signaling may underlie the inability of mature OLs, found in chronic MS lesions, to generate new myelin internodes. Understanding the molecular mechanisms and signaling pathways that drive the process of new myelin generation is a critical first step toward the design of new, effective MS therapies.

\section{References}

Arnett HA, Fancy SP, Alberta JA, Zhao C, Plant SR, Kaing S, Raine CS, Rowitch DH, Franklin RJ, Stiles CD (2004) bHLH transcription factor Olig1 is required to repair demyelinated lesions in the CNS. Science 306: 2111-2115. CrossRef Medline

Barbarese E, Koppel DE, Deutscher MP, Smith CL, Ainger K, Morgan F, Carson JH (1995) Protein translation components are colocalized in granules in oligodendrocytes. J Cell Sci 108:2781-2790. Medline

Bauer NM, Moos C, van Horssen J, Witte M, van der Valk P, Altenhein B, Luhmann HJ, White R (2012) Myelin basic protein synthesis is regulated by small non-coding RNA 715. EMBO Rep 13:827-834. CrossRef Medline

Bercury KK, Dai J, Sachs HH, Ahrendsen JT, Wood TL, Macklin WB (2014) Conditional ablation of raptor or rictor has differential impact on oligodendrocyte differentiation and CNS myelination. J Neurosci 34:44664480. CrossRef Medline
Bhat NR, Zhang P (1996) Activation of mitogen-activated protein kinases in oligodendrocytes. J Neurochem 66:1986-1994. CrossRef Medline

Bibollet-Bahena O, Almazan G (2009) IGF-1-stimulated protein synthesis in oligodendrocyte progenitors requires $\mathrm{PI} 3 \mathrm{~K} / \mathrm{mTOR} /$ Akt and MEK/ERK pathways. J Neurochem 109:1440-1451. CrossRef Medline

Blakemore WF, Franklin RJ (2008) Remyelination in experimental models of toxin-induced demyelination. Curr Top Microbiol Immunol 318:193212. Medline

Chan YL, Wool IG (1988) The primary structure of rat ribosomal protein S6. J Biol Chem 263:2891-2896. Medline

Chang A, Nishiyama A, Peterson J, Prineas J, Trapp BD (2000) NG2positive oligodendrocyte progenitor cells in adult human brain and multiple sclerosis lesions. J Neurosci 20:6404-6412. Medline

Chang A, Tourtellotte WW, Rudick R, Trapp BD (2002) Premyelinating oligodendrocytes in chronic lesions of multiple sclerosis. N Engl J Med 346:165-173. CrossRef Medline

Colman DR, Kreibich G, Frey AB, Sabatini DD (1982) Synthesis and incorporation of myelin polypeptides into CNS myelin. J Cell Biol 95:598-608. CrossRef Medline

Czopka T, ffrench-Constant C, Lyons DA (2013) Individual oligodendrocytes have only a few hours in which to generate new myelin sheaths in vivo. Dev Cell 25:599-609. CrossRef Medline

Dai J, Bercury KK, Macklin WB (2014) Interaction of mTOR and Erk1/2 signaling to regulate oligodendrocyte differentiation. Glia 62:2096-2109. CrossRef Medline

Dai J, Bercury KK, Ahrendsen JT, Macklin WB (2015) Olig1 function is required for oligodendrocyte differentiation in the mouse brain. J Neurosci 35:4386-4402. CrossRef Medline

del Prete MJ, Vernal R, Dolznig H, Müllner EW, Garcia-Sanz JA (2007) Isolation of polysome-bound mRNA from solid tissues amenable for RTPCR and profiling experiments. RNA 13:414-421. CrossRef Medline

Domowicz MS, Sanders TA, Ragsdale CW, Schwartz NB (2008) Aggrecan is expressed by embryonic brain glia and regulates astrocyte development. Dev Biol 315:114-124. CrossRef Medline

Du Y, Lercher LD, Zhou R, Dreyfus CF (2006) Mitogen-activated protein kinase pathway mediates effects of brain-derived neurotrophic factor on differentiation of basal forebrain oligodendrocytes. J Neurosci Res 84: 1692-1702. CrossRef Medline

Duncan ID, Brower A, Kondo Y, Curlee JF Jr, Schultz RD (2009) Extensive remyelination of the CNS leads to functional recovery. Proc Natl Acad Sci U S A 106:6832-6836. CrossRef Medline

Fancy SP, Baranzini SE, Zhao C, Yuk DI, Irvine KA, Kaing S, Sanai N, Franklin RJ, Rowitch DH (2009) Dysregulation of the Wnt pathway inhibits timely myelination and remyelination in the mammalian CNS. Genes Dev 23:1571-1585. CrossRef Medline

Fancy SP, Chan JR, Baranzini SE, Franklin RJ, Rowitch DH (2011) Myelin regeneration: a recapitulation of development? Annu Rev Neurosci 34: 21-43. CrossRef Medline

Ferent J, Zimmer C, Durbec P, Ruat M, Traiffort E (2013) Sonic Hedgehog signaling is a positive oligodendrocyte regulator during demyelination. J Neurosci 33:1759-1772. CrossRef Medline

Ferrari S, Bandi HR, Hofsteenge J, Bussian BM, Thomas G (1991) Mitogenactivated 70K S6 kinase. Identification of in vitro $40 \mathrm{~S}$ ribosomal S6 phosphorylation sites. J Biol Chem 266:22770-22775. Medline

Franklin RJ, ffrench-Constant C (2008) Remyelination in the CNS: from biology to therapy. Nat Rev Neurosci 9:839-855. CrossRef Medline

Furusho M, Dupree JL, Nave KA, Bansal R (2012) Fibroblast growth factor receptor signaling in oligodendrocytes regulates myelin sheath thickness. J Neurosci 32:6631-6641. CrossRef Medline

Fyffe-Maricich SL, Karlo JC, Landreth GE, Miller RH (2011) The ERK2 mitogen-activated protein kinase regulates the timing of oligodendrocyte differentiation. J Neurosci 31:843-850. CrossRef Medline

Fyffe-Maricich SL, Schott A, Karl M, Krasno J, Miller RH (2013) Signaling through ERK1/2 controls myelin thickness during myelin repair in the adult central nervous system. J Neurosci 33:18402-18408. CrossRef Medline

Galabova-Kovacs G, Catalanotti F, Matzen D, Reyes GX, Zezula J, Herbst R, Silva A, Walter I, Baccarini M (2008) Essential role of B-Raf in oligodendrocyte maturation and myelination during postnatal central nervous system development. J Cell Biol 180:947-955. CrossRef Medline

Gallo V, Deneen B (2014) Glial development: the crossroads of regeneration and repair in the CNS. Neuron 83:283-308. CrossRef Medline 
Garcia-Ladona FJ, Huss Y, Frey P, Ghandour MS (1997) Oligodendrocytes express different isoforms of beta-amyloid precursor protein in chemically defined cell culture conditions: in situ hybridization and immunocytochemical detection. J Neurosci Res 50:50-61. CrossRef Medline

Ghandour MS, Skoff RP (1991) Double-labeling in situ hybridization analysis of mRNAs for carbonic anhydrase II and myelin basic protein: expression in developing cultured glial cells. Glia 4:1-10. CrossRef Medline

Griffiths I, Klugmann M, Anderson T, Yool D, Thomson C, Schwab MH, Schneider A, Zimmermann F, McCulloch M, Nadon N, Nave KA (1998) Axonal swellings and degeneration in mice lacking the major proteolipid of myelin. Science 280:1610-1613. CrossRef Medline

Guardiola-Diaz HM, Ishii A, Bansal R (2012) Erk1/2 MAPK and mTOR signaling sequentially regulates progression through distinct stages of oligodendrocyte differentiation. Glia 60:476-486. CrossRef Medline

Guégan JP, Ezan F, Gailhouste L, Langouët S, Baffet G (2014) MEK1/2 overactivation can promote growth arrest by mediating ERK1/2-dependent phosphorylation of p70S6K. J Cell Physiol 229:903-915. CrossRef Medline

Hammond TR, Gadea A, Dupree J, Kerninon C, Nait-Oumesmar B, Aguirre A, Gallo V (2014) Astrocyte-derived endothelin-1 inhibits remyelination through notch activation. Neuron 81:588-602. CrossRef Medline

Harrington EP, Zhao C, Fancy SP, Kaing S, Franklin RJ, Rowitch DH (2010) Oligodendrocyte PTEN is required for myelin and axonal integrity, not remyelination. Ann Neurol 68:703-716. CrossRef Medline

Hauge C, Frödin M (2006) RSK and MSK in MAP kinase signalling. J Cell Sci 119:3021-3023. CrossRef Medline

Holz A, Schaeren-Wiemers N, Schaefer C, Pott U, Colello RJ, Schwab ME (1996) Molecular and developmental characterization of novel cDNAs of the myelin-associated/oligodendrocytic basic protein. J Neurosci 16: 467-477. Medline

Ishii A, Fyffe-Maricich SL, Furusho M, Miller RH, Bansal R (2012) ERK1/ ERK2 MAPK signaling is required to increase myelin thickness independent of oligodendrocyte differentiation and initiation of myelination. J Neurosci 32:8855-8864. CrossRef Medline

Ishii A, Furusho M, Bansal R (2013) Sustained activation of ERK1/2 MAPK in oligodendrocytes and Schwann cells enhances myelin growth and stimulates oligodendrocyte progenitor expansion. J Neurosci 33:175-186. CrossRef Medline

Jeffery ND, Blakemore WF (1995) Remyelination of mouse spinal cord axons demyelinated by local injection of lysolecithin. J Neurocytol 24:775781. CrossRef Medline

Jeffery ND, Blakemore WF (1997) Locomotor deficits induced by experimental spinal cord demyelination are abolished by spontaneous remyelination. Brain 120:27-37. CrossRef Medline

Kelleher RJ 3rd, Govindarajan A, Jung HY, Kang H, Tonegawa S (2004) Translational control by MAPK signaling in long-term synaptic plasticity and memory. Cell 116:467-479. CrossRef Medline

Kotter MR, Stadelmann C, Hartung HP (2011) Enhancing remyelination in disease-can we wrap it up? Brain 134:1882-1900. CrossRef Medline

Kuhlmann T, Miron V, Cui Q, Wegner C, Antel J, Brück W (2008) Differentiation block of oligodendroglial progenitor cells as a cause for remyelination failure in chronic multiple sclerosis. Brain 131:1749-1758. CrossRef Medline

Lappe-Siefke C, Goebbels S, Gravel M, Nicksch E, Lee J, Braun PE, Griffiths IR, Nave KA (2003) Disruption of Cnp1 uncouples oligodendroglial functions in axonal support and myelination. Nat Genet 33:366-374. CrossRef Medline

Laursen LS, Chan CW, ffrench-Constant C (2009) An integrin-contactin complex regulates CNS myelination by differential Fyn phosphorylation. J Neurosci 29:9174-9185. CrossRef Medline

Laursen LS, Chan CW, ffrench-Constant C (2011) Translation of myelin basic protein mRNA in oligodendrocytes is regulated by integrin activation and hnRNP-K. J Cell Biol 192:797-811. CrossRef Medline

Lebrun-Julien F, Bachmann L, Norrmén C, Trötzmüller M, Köfeler H, Rüegg MA, Hall MN, Suter U (2014) Balanced mTORC1 activity in oligodendrocytes is required for accurate CNS myelination. J Neurosci 34:84328448. CrossRef Medline

Lehman JA, Calvo V, Gomez-Cambronero J (2003) Mechanism of ribosomal p70S6 kinase activation by granulocyte macrophage colonystimulating factor in neutrophils: cooperation of a MEK-related, THR421/SER424 kinase and a rapamycin-sensitive, m-TOR-related THR389 kinase. J Biol Chem 278:28130-28138. CrossRef Medline
Li C, Tropak MB, Gerlai R, Clapoff S, Abramow-Newerly W, Trapp B, Peterson A, Roder J (1994) Myelination in the absence of myelin-associated glycoprotein. Nature 369:747-750. CrossRef Medline

LoPresti P, Szuchet S, Papasozomenos SC, Zinkowski RP, Binder LI (1995) Functional implications for the microtubule-associated protein tau: localization in oligodendrocytes. Proc Natl Acad Sci U S A 92:1036910373. CrossRef Medline

Lu QR, Sun T, Zhu Z, Ma N, Garcia M, Stiles CD, Rowitch DH (2002) Common developmental requirement for Olig function indicates a motor neuron/oligodendrocyte connection. Cell 109:75-86. CrossRef Medline

Lucchinetti CF, Brück W, Rodriguez M, Lassmann H (1996) Distinct patterns of multiple sclerosis pathology indicates heterogeneity on pathogenesis. Brain Pathol 6:259-274. CrossRef Medline

Mašek T, Valáĕk L, Pospíšek M (2011) Polysome analysis and RNA purification from sucrose gradients. Methods Mol Biol 703:293-309. CrossRef Medline

Miller RH (2002) Regulation of oligodendrocyte development in the vertebrate CNS. Prog Neurobiol 67:451-467. CrossRef Medline

Miller RH, Mi S (2007) Dissecting demyelination. Nat Neurosci 10:13511354. CrossRef Medline

Molineaux SM, Engh H, de Ferra F, Hudson L, Lazzarini RA (1986) Recombination within the myelin basic protein gene created the dysmyelinating shiverer mouse mutation. Proc Natl Acad Sci U S A 83:7542-7546. CrossRef Medline

Nait-Oumesmar B, Decker L, Lachapelle F, Avellana-Adalid V, Bachelin C, Baron-Van Evercooren A (1999) Progenitor cells of the adult mouse subventricular zone proliferate, migrate and differentiate into oligodendrocytes after demyelination. Eur J Neurosci 11:4357-4366. CrossRef Medline

Orentas DM, Hayes JE, Dyer KL, Miller RH (1999) Sonic hedgehog signaling is required during the appearance of spinal cord oligodendrocyte precursors. Development 126:2419-2429. Medline

Patrikios P, Stadelmann C, Kutzelnigg A, Rauschka H, Schmidbauer M, Laursen H, Sorensen PS, Brück W, Lucchinetti C, Lassmann H (2006) Remyelination is extensive in a subset of multiple sclerosis patients. Brain 129:3165-3172. CrossRef Medline

Pende M, Um SH, Mieulet V, Sticker M, Goss VL, Mestan J, Mueller M, Fumagalli S, Kozma SC, Thomas G (2004) S6K1(-/-)/S6K2(-/-) mice exhibit perinatal lethality and rapamycin-sensitive 5 '-terminal oligopyrimidine mRNA translation and reveal a mitogen-activated protein kinase-dependent S6 kinase pathway. Mol Cell Biol 24:3112-3124. CrossRef Medline

Pérez MJ, Fernandez N, Pasquini JM (2013) Oligodendrocyte differentiation and signaling after transferrin internalization: a mechanism of action. Exp Neurol 248:262-274. CrossRef Medline

Prineas JW, Connell F (1979) Remyelination in multiple sclerosis. Ann Neurol 5:22-31. CrossRef Medline

Pullen N, Thomas G (1997) The modular phosphorylation and activation of p70s6k. FEBS Lett 410:78-82. CrossRef Medline

Raught B, Peiretti F, Gingras AC, Livingstone M, Shahbazian D, Mayeur GL, Polakiewicz RD, Sonenberg N, Hershey JW (2004) Phosphorylation of eucaryotic translation initiation factor $4 \mathrm{~B}$ Ser422 is modulated by S6 kinases. EMBO J 23:1761-1769. CrossRef Medline

Roach A, Takahashi N, Pravtcheva D, Ruddle F, Hood L (1985) Chromosomal mapping of mouse myelin basic protein gene and structure and transcription of the partially deleted gene in shiverer mutant mice. Cell 42:149-155. CrossRef Medline

Roux PP, Shahbazian D, Vu H, Holz MK, Cohen MS, Taunton J, Sonenberg N, Blenis J (2007) RAS/ERK signaling promotes site-specific ribosomal protein S6 phosphorylation via RSK and stimulates cap-dependent translation. J Biol Chem 282:14056-14064. CrossRef Medline

Samuels IS, Karlo JC, Faruzzi AN, Pickering K, Herrup K, Sweatt JD, Saitta SC, Landreth GE (2008) Deletion of ERK2 mitogen-activated protein kinase identifies its key roles in cortical neurogenesis and cognitive function. J Neurosci 28:6983-6995. CrossRef Medline

Sheean ME, McShane E, Cheret C, Walcher J, Müller T, Wulf-Goldenberg A, Hoelper S, Garratt AN, Krüger M, Rajewsky K, Meijer D, Birchmeier W, Lewin GR, Selbach M, Birchmeier C (2014) Activation of MAPK overrides the termination of myelin growth and replaces Nrg1/ErbB3 signals during Schwann cell development and myelination. Genes Dev 28:290 303. CrossRef Medline

Shi Y, Hsu JH, Hu L, Gera J, Lichtenstein A (2002) Signal pathways involved 
in activation of p70S6 $\mathrm{K}$ and phosphorylation of 4E-BP1 following exposure of multiple myeloma tumor cells to interleukin-6. J Biol Chem 277: 15712-15720. CrossRef Medline

Smith KJ, Blakemore WF, McDonald WI (1979) Central remyelination restores secure conduction. Nature 280:395-396. CrossRef Medline

Smith KJ, Blakemore WF, McDonald WI (1981) The restoration of conduction by central remyelination. Brain 104:383-404. CrossRef Medline

Spassky N, Heydon K, Mangatal A, Jankovski A, Olivier C, Queraud-Lesaux F, Goujet-Zalc C, Thomas JL, Zalc B (2001) Sonic hedgehog-dependent emergence of oligodendrocytes in the telencephalon: evidence for a source of oligodendrocytes in the olfactory bulb that is independent of PDGFRalpha signaling. Development 128:4993-5004. Medline

Sun X, Liu Y, Liu B, Xiao Z, Zhang L (2012) Rolipram promotes remyelination possibly via MEK-ERK signal pathway in cuprizone-induced demyelination mouse. Exp Neurol 237:304-311. CrossRef Medline

Tyler WA, Gangoli N, Gokina P, Kim HA, Covey M, Levison SW, Wood TL (2009) Activation of the mammalian target of rapamycin (mTOR) is essential for oligodendrocyte differentiation. J Neurosci 29:6367-6378. CrossRef Medline

Wahl SE, McLane LE, Bercury KK, Macklin WB, Wood TL (2014) Mammalian target of rapamycin promotes oligodendrocyte differentiation, initiation and extent of CNS myelination. J Neurosci 34:4453-4465. CrossRef Medline

Wake H, Lee PR, Fields RD (2011) Control of local protein synthesis and initial events in myelination by action potentials. Science 333:1647-1651. CrossRef Medline

Wang X, Li W, Williams M, Terada N, Alessi DR, Proud CG (2001) Regulation of elongation factor 2 kinase by p90(RSK1) and p70 S6 kinase. EMBO J 20:4370-4379. CrossRef Medline

Warner JR, Knopf PM, Rich A (1963) A multiple ribosomal structure in protein synthesis. Proc Natl Acad Sci U S A 49:122-129. CrossRef Medline

Watkins TA, Emery B, Mulinyawe S, Barres BA (2008) Distinct stages of myelination regulated by gamma-secretase and astrocytes in a rapidly myelinating CNS coculture system. Neuron 60:555-569. CrossRef Medline

Weng QP, Kozlowski M, Belham C, Zhang A, Comb MJ, Avruch J (1998) Regulation of the p70 S6 kinase by phosphorylation in vivo. Analysis using site-specific anti-phosphopeptide antibodies. J Biol Chem 273: 16621-16629. CrossRef Medline

White R, Gonsior C, Krämer-Albers EM, Stöhr N, Hüttelmaier S, Trotter J (2008) Activation of oligodendroglial Fyn kinase enhances translation of mRNAs transported in hnRNP A2-dependent RNA granules. J Cell Biol 181:579-586. CrossRef Medline

White R, Gonsior C, Bauer NM, Krämer-Albers EM, Luhmann HJ, Trotter J (2012) Heterogeneous nuclear ribonucleoprotein (hnRNP) F is a novel component of oligodendroglial RNA transport granules contributing to regulation of myelin basic protein (MBP) synthesis. J Biol Chem 287: 1742-1754. CrossRef Medline

Wolswijk G (1998) Chronic stage multiple sclerosis lesions contain a relatively quiescent population of oligodendrocyte precursor cells. J Neurosci 18:601-609. Medline

Wood TL, Bercury KK, Cifelli SE, Mursch LE, Min J, Dai J, Macklin WB (2013) mTOR: a link from the extracellular milieu to transcriptional regulation of oligodendrocyte development. ASN Neuro 5:e00108. CrossRef Medline

Xiao J, Ferner AH, Wong AW, Denham M, Kilpatrick TJ, Murray SS (2012) Extracellular signal-regulated kinase 1/2 signaling promotes oligodendrocyte myelination in vitro. J Neurochem 122:1167-1180. CrossRef Medline

Xiao L, Guo D, Hu C, Shen W, Shan L, Li C, Liu X, Yang W, Zhang W, He C (2012) Diosgenin promotes oligodendrocyte progenitor cell differentiation through estrogen receptor-mediated ERK1/2 activation to accelerate remyelination. Glia 60:1037-1052. CrossRef Medline

Younes-Rapozo V, Felgueiras LO, Viana NL, Fierro IM, Barja-Fidalgo C, Manhães AC, Barradas PC (2009) A role for the MAPK/ERK pathway in oligodendroglial differentiation in vitro: stage specific effects on cell branching. Int J Dev Neurosci 27:757-768. CrossRef Medline 